\title{
Status changes, new synonymies, key and descriptions of seven new species in the subgenus Scarabaeus (Scarabaeolus) Balthasar 1965 (Coleoptera: Scarabaeidae: Scarabaeinae)
}

\author{
CHRISTIAN M. DESCHODT ${ }^{1,2}$, ADRIAN L.V. DAVIS ${ }^{2}$ and CLARKE H. SCHOLTZ ${ }^{2}$. \\ ${ }^{I}$ Department of Zoology and Entomology, Rhodes University, Grahamstown, South Africa \\ ${ }^{2}$ Department of Zoology and Entomology, University of Pretoria, Pretoria, South Africa.
}

Christian Deschodt, e-mail: cdeschodt@zoology.up.ac.za

\begin{abstract}
Distribution of the subgenus Scarabaeus (Scarabaeolus) Balthasar 1965 (tribe Scarabaeini) is centred on southern and south central Africa with only three out of 27 species recorded from West and northeast Africa. After taxonomic corrections and descriptions of seven new southern African species this somewhat controversial subgenus now comprises 33 valid species of which one is flightless. In this paper, Scarabaeus (Scarabaeolus) vansoni Ferreira 1958 syn. nov. is synonymized with Scarabaeus (Scarabaeolus) lucidulus (Boheman 1860) and Scarabaeus (Scarabaeolus) xavieri Ferreira 1968 syn. nov. is synonymized with Scarabaeus (Scarabaeolus) andreaei zur Strassen 1963. Scarabaeus (Scarabaeolus) reichei Waterhouse 1890 stat. rev. is removed from synonymy with Scarabaeus (Scarabaeolus) canaliculatus Fairmaire, 1888 and reinstated as a valid species. Distribution maps for $S$. (S.) reichei, S. (S.) canaliculatus and a third close relative, Scarabaeus (Scarabaeolus) fritschi Harold 1868 are provided. The seven new species comprise: Scarabaeus (Scarabaeolus) soutpansbergensis Deschodt and Davis spec. nov., Scarabaeus (Scarabaeolus) megaparvulus Davis and Deschodt spec. nov., Scarabaeus (Scarabaeolus) niemandi Deschodt and Davis spec. nov., Scarabaeus (Scarabaeolus) carniphilus Davis and Deschodt spec. nov., Scarabaeus (Scarabaeolus) ermienae Deschodt and Davis spec. nov., Scarabaeus (Scarabaeolus) planipennis Davis and Deschodt spec. nov. and Scarabaeus (Scarabaeolus) nitidus Davis and Deschodt spec. nov. A key is provided for all the known winged species together with notes on some of the previously described species.
\end{abstract}

Key words: Botswana, South Africa, Mozambique, Zambia, Scarabaeidae, new species, synonymies, status revised, key.

\section{Introduction}

The status of genera and subgenera within the tribe, Scarabaeini, has a long and confused history that continues to the present day (Zidek \& Pokorny 2004, Forgie et al. 2006). At the 
current time, the composition of the tribe depends on which authority one follows. Here, our classification follows that of Forgie et al. (2006) who divided the Afrotropical members of the tribe into three genera (Pachylomera Griffith \& Pidgeon 1831, Pachysoma Macleay 1821 and Scarabaeus L. 1758) and four subgenera of Scarabaeus (Scarabaeus (Kheper) Janssens 1940, Scarabaeus (Sceliages) Westwood 1837, Scarabaeus (Scarabaeus) L. 1758 and Scarabaeus (Scarabaeolus) Balthasar 1965).

Even with this structure, we accept that classification of the tribe remains controversial and may require further revision. Recently Pachysoma was reduced to subgeneric status within Scarabaeus by Harrison et al. (2003), listed under Scarabaeus by Zidek \& Pokorny (2004), but subsequently revalidated (Forgie et al. 2006). Other recent reductions of long-established Afrotropical genera (Kheper, Sceliages) to subgeneric status within Scarabaeus, (Forgie et al. 2005) may, like Pachysoma, also deserve review and revalidation as full genera on morphological, molecular and behavioral grounds. This applies particularly to Sceliages, which shows modification of the clypeal margin associated with the specialized use of millipede gut contents for breeding (Forgie et al. 2002).

In the case of the earlier division of Scarabaeus s. str. into two subgenera Balthasar (1965) the separation was based, primarily, on the presence of a vestigial second mesotibial spur in Scarabaeus (Scarabaeolus) and its absence in Scarabaeus (Scarabaeus). Other cited characters for Scarabaeus (Scarabaeolus) included: the absence of an overhanging elytral edge; widely separated, parallel, lateral carinae; small size (length: 10-14 mm); and elytra tapering posteriorly. However, as Balthasar (1965) noted that the principal character was apparently not universal (i.e. Scarabaeus (Scarabaeolus) palemo Olivier 1789 has a single mesotibial spur), subsequent workers differed in opinion with zur Strassen (1967) and Zidek \& Pokorny (2004) failing to recognize the subgenus whereas Mostert \& Scholtz (1986) noted that most species have the second spur.

Although recognition of the subgenus is not universal, of the 27 Scarabaeolus species, currently known, 24 show a regionally restricted distribution pattern (Davis et al. 2008) centred on southern and southern central Africa. Furthermore, one observation of a Scarabaeus (Scarabaeolus) bohemani (Harold 1868) female following a male rolling a ball (Tribe 1976) suggests that members of the subgenus may also show behavioral differences to Scarabaeus (Scarabaeus) species in which the female clings to the side of a ball being rolled by the male (Sato 1998). In addition, the preferred morphological phylogenetic analysis of Afrotropical Scarabaeini (Forgie et al. 2005) divides the tribal members into a number of clades, one of which includes Scarabaeolus species. However, in view of the controversy, comprehensive molecular analysis would be desirable to support the higher classification of the tribe.

On the understanding that stronger support for Scarabaeolus as a valid entity is pending, here, we revise the alpha taxonomy by synonymizing two species, revalidating one previously synonymized species, and describing seven others as new. This raises the total number of species to 33 for the subgenus. These comprise 30 southern or Southern Central African species and three that are west or pan-African centred, or are found in northeast 
Africa, including one flightless taxon (Scarabaeus (Scarabaeolus) scholtzi Mostert and Holm 1982), possibly misplaced, in the subgenus.

\section{Materials and methods}

In this study we examined specimens and photographs of specimens housed in the following depositories:

BMNH: London, United Kingdom, Natural History Museum

MNHN: France, Paris, Muséum National d'Histoire Naturelle

NHRS: Sweden, Stockholm, Naturhistoriska Riksmuseet

SANC: South Africa, Pretoria, South African National Collection of Insects

SAMC: South Africa, Cape Town, Iziko South African Museum

TMSA: South Africa, Gauteng, Pretoria, Ditsong National Museum of Natural History

UPSA: South Africa, Pretoria, University of Pretoria

The order which the descriptions follow is the same as the species key out in the key below.

Locality labels are reported verbatim with author comments in square brackets.

Color photographs were obtained using a Canon 500D body with either a Canon 100mm macro lens or Canon 65mm MPE 1-5x zoom lens. Image stacking was done using Helicon remote and Helicon focus software.

\section{New synonymies and status revision in the subgenus Scarabaeus (Scarabaeolus)}

Scarabaeus (Scarabaeolus) lucidulus (Boheman, 1860)

Scarabaeus (Scarabaeolus) vansoni Ferreira 1958 new synonym

We have compared photographs of both the type specimens of Scarabaeus (Scarabaeolus) lucidulus (Boheman, 1860), housed in the NHRS (type locality: Lake Ngami, N. Botswana), with the holotype of Scarabaeus (Scarabaeolus) vansoni Ferreira 1958, housed in the TMSA (type locality: Mangetti, Ovamboland, N. Namibia) (Fig. 1), and are of the opinion that they are synonymous. The type of $S$. (S.) lucidulus is female thus aedeagi could not be compared. However punctuation of the prothoracic disc is similar in both type specimens and the interstriae are similarly lacking in punctuation. 


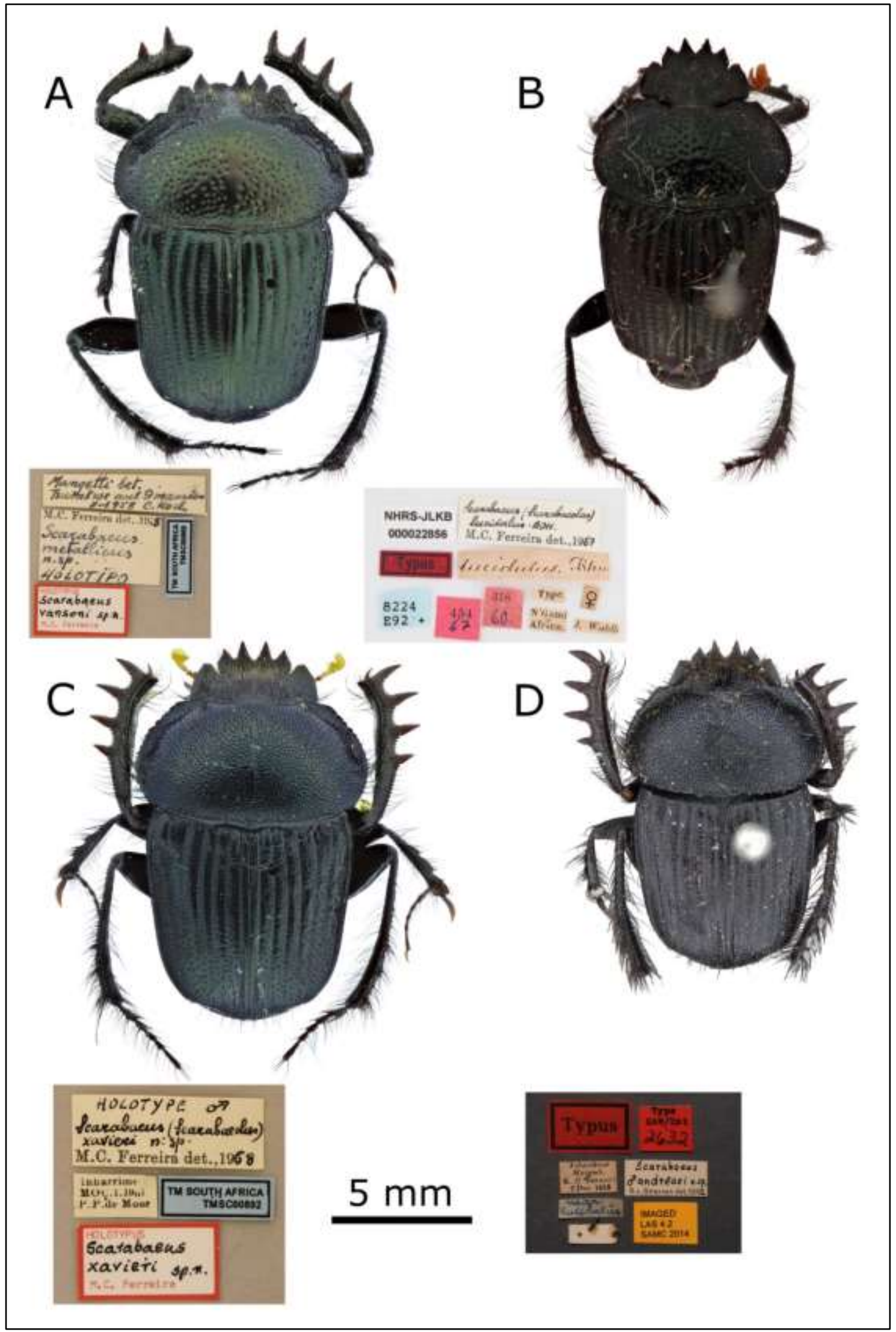

Figure 1. Dorsal views of (A) S. (S.) vansoni, (B) S. (S.) lucidulus (@ SANC, photographed by Simon Van Noordt), (C) S. (S.) xavieri and (D) $S$. (S.) andreaei (@NHRS photographed by Johannes Bergsten) with associated labels to show synonymies. 
Scarabaeus (Scarabaeolus) xavieri Ferreira 1968 new synonym

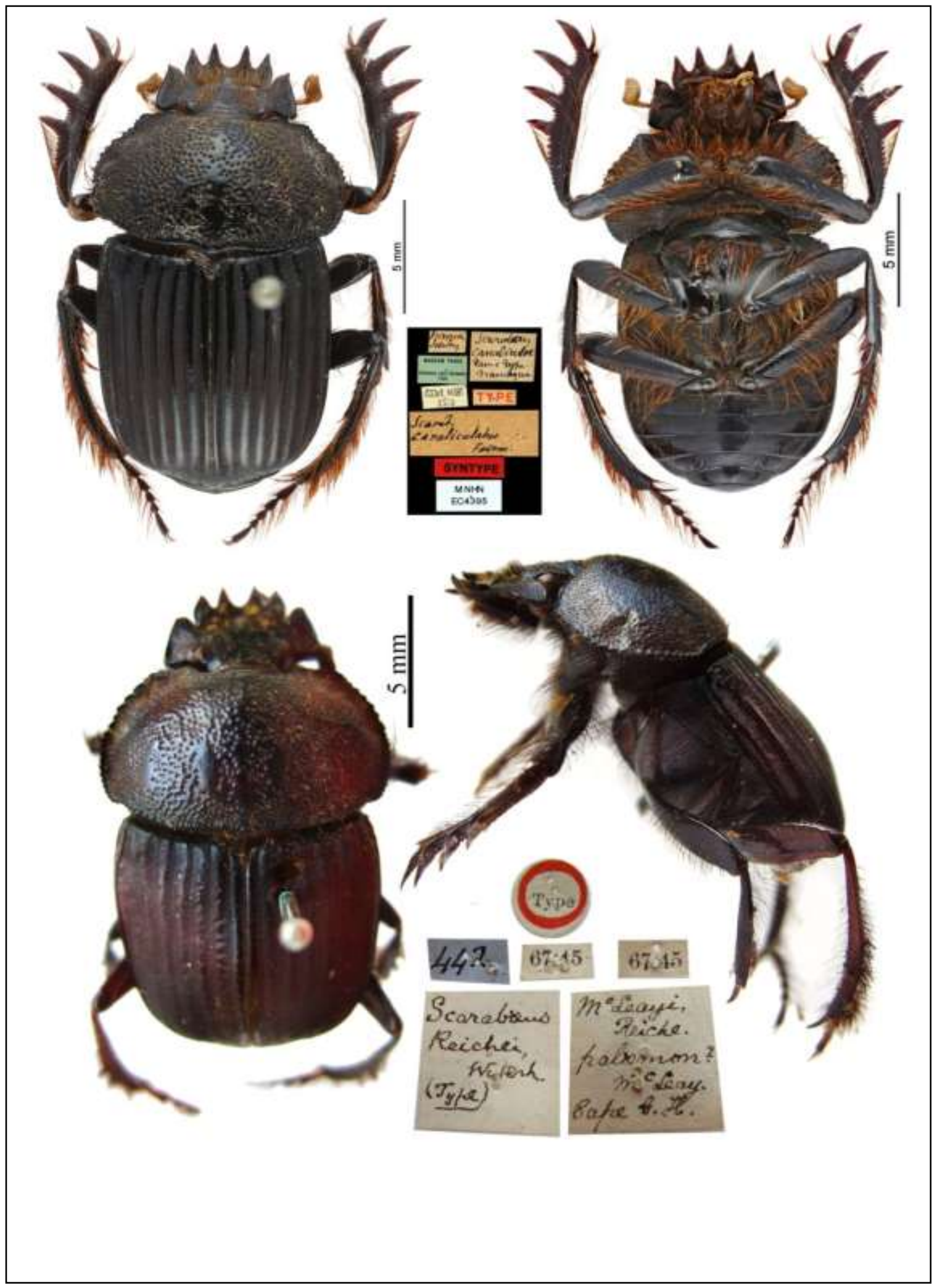

Figure 2. Dorsal and ventral views of $S$. (S.) canaliculatus with associated labels (@ MNHN, photographed by Antoine Mantilleri) and dorsal and lateral views of $S$. (S.) reichei with associated labels (C BMNH, photographed by Helena Maratheftis). 
We have compared photographs of the holotype and paratype specimens of Scarabaeus (Scarabaeolus) andreaei Zur Strassen 1963, housed in the SAMC (type locality: Inhambane, coastal Mozambique), with the holotype of Scarabaeus (Scarabaeolus) xavieri Ferreira 1968, housed in the TMSA (type locality: Inharrime, coastal Mozambique) (Fig. 1), and are of the opinion that they are synonymous. The type of $S$. (S.) andreaei is female thus aedeagi could not be compared. However the fine dense punctuation of the prothoracic disc and slightly convex interstriae is similar in both type specimens.

Scarabaeus (Scarabaeolus) reichei Waterhouse 1890 stat. rev.

Gillet (1911) synonymized Scarabaeus (Scarabaeolus) reichei Waterhouse 1890 with Scarabaeus (Scarabaeolus) canaliculatus Fairmaire 1888. Subsequently, this decision was followed by Janssens (1940), Zur Strassen (1967), Ferreira (1972) and Zidek \& Pokorny (2004). However, photographs of the type specimen of $S$. (S.) canaliculatus (Fig. 2) show strongly convex interstriae, tan pilosity and yellow antennae that are comparable to specimens recently collected in southern Namibia whose distribution (Fig. 7) coincides with the "Namaqua" type locality of $S$. (S.) canaliculatus (Fairmaire 1888) [interpreted as Great Namaqualand or the Karas Region in Namibia]. The photographs of $S$. (S.) canaliculatus differ to those of the type specimen of $S$. (S.) reichei (Fig. 2) that show flat interstriae, dark pilosity and dark antennae comparable to many specimens recorded from the west coast of South Africa whose distribution (Fig. 7) coincides with the "Cape of Good Hope" type locality of $S$. (S.) reichei (Waterhouse 1890). The photographs also differ from many specimens recorded from the interior of southern Africa that show strongly convex interstriae, dark pilosity and dark antennae, whose distribution (Fig. 7) coincides with the "Afric. austral. inter." [Interior of Southern Africa] type locality of Scarabaeus (Scarabaeolus) fritschi (Harold, 1868) (type not located). Thus, Scarabaeus (Scarabaeolus) reichei Waterhouse 1890 is removed from synonymy with Scarabaeus (Scarabaeolus) canaliculatus Fairmaire 1888 and is reinstated as a valid species.

\section{Descriptions of new species}

\section{Scarabaeus (Scarabaeolus) soutpansbergensis Deschodt and Davis}

Figure 3, 8

Diagnosis. This new species is probably most closely related to Scarabaeus (Scarabaeolus) clanceyi Ferreira 1954 but does not have the characteristic hook on the posterior margin of the hind femur, which characterizes that species. It may be separated from Scarabaeus (Scarabaeolus) palemo Olivier, 1789 and Scarabaeus (Scarabaeolus) bohemani Harold, 1868 by the medial swelling of the hind femora and by the orange brown antennae compared to black antennae in $S$. (S.) bohemani and $S$. (S.) palemo. It is also much smaller than all the other Scarabaeolus species except Scarabaeus (Scarabaeolus) parvulus (Boheman, 1860). The male of this new species is unknown. 


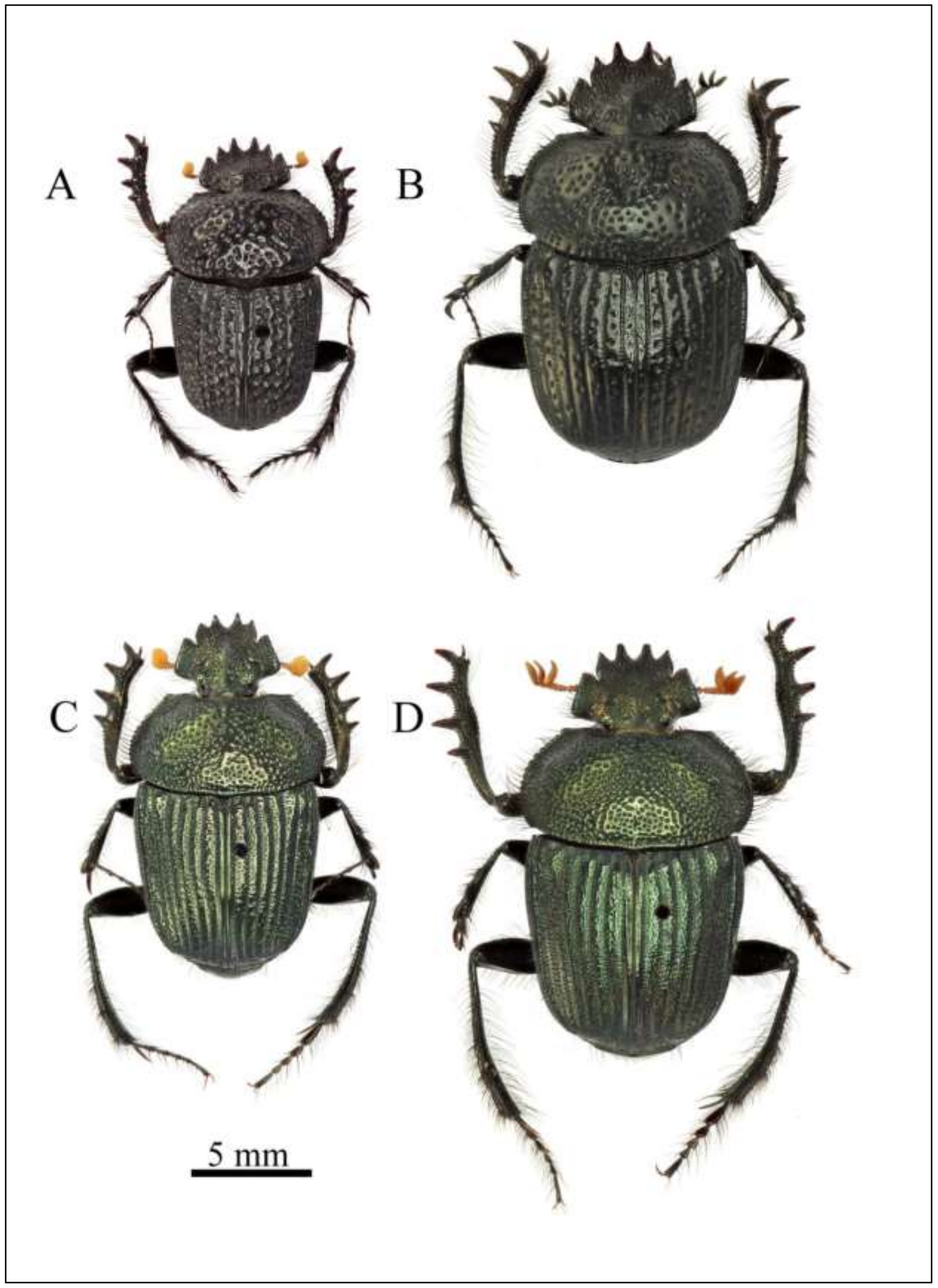

Figure 3. A. S. (S.) soutpansbergensis. B. S. (S.) megaparvulus. C. S. (S.) niemandi. D. S. (S.) carniphilus. Scales for figures 2,3 and 4 are the same. 
Description. Holotype: Body length $10.1 \mathrm{~mm}$, black. Pubescence black, except on frons where it is dark brown and pronotum where it is orange. Antennae orange brown.

Head: Frons punctate with iso-diametric punctures and dark brown associated setae. Low puncture-free carina present longitudinally between eyes. Clypeus punctate with punctures extended longitudinally.

Pronotum: Black, punctate, space between punctures smooth, punctures forming deep pits, separated by less than one pit diameter, punctures with short orange associated setae. No longitudinal smooth area. Lateral margins curved, crenulate.

Elytra: Black, lateral sides more or less parallel. Striae deep with regular small punctures, punctures separated by less than two puncture diameters. Interstriae matte bearing deep irregular shaped pits that are mostly matte inside; pits are wider than interstriae creating rugose appearance.

Pygidium: Emarginate and somewhat punctate; inside matte with area outside of punctures smooth. Punctures spaced irregularly, sometimes touching or separated by up to two and a half times the puncture width.

Metasternum: Long fovea between the mesocoxae, medially widest, with a second shorter fovea more distally. Metasternal elevation ending in almost a right angle and steeply sloping toward mesosternum. Area behind mesocoxae punctate, punctures small and widely separated.

Abdominal sternites: Glabrous with shallow indentations laterally.

Legs: Anterior femora shallowly punctate ventrally with dark setae dorsally. Inside margin of anterior tibiae crenulate, outside margin crenulate proximally with four outward pointing teeth distally, each separated by two to four saw-like denticles; denticles between last two teeth fused. Meso- and metafemora with irregular median row of punctures and dark setae. Metafemora swollen medially to give appearance of emargination on either end, inside edge of swollen area flattened. Mesotibiae slender, inside margin smooth and with row of black setae, outside margin with two brushes of black setae in distal third. Vestigial second mesotibial spur absent. Metatibiae with black setae, three bulges distally on outside. All tarsomeres of metatarsi with black setae, last tarsomere longest with claws half its length.

Etymology: The species is named for the Soutpansberg Mountains that dominate the area where it was collected.

Material examined: Holotype: \#F, S.Afr.; Limpopo Prov., Messina Nat. Res., 22[].21['] S $\left.30^{\circ}\right] .03[$ ['] E, 11.12.2000;E-Y:3396, general collecting, leg.M.Burger,R.Müller, TMSA. Paratype: 1 specimen \#F, Soutpansberg, Limpopo, S22.91579²E29.68756º 3-4.ii.2009, L. J. Niemand, UPSA. 


\section{Scarabaeus (Scarabaeolus) megaparvulus Davis and Deschodt}

Figure 3, 6, 9

Diagnosis. This new species can be separated from $S$. (S.) parvulus by not having the anterior pronotal corners drawn forward into a hooked tip. In general, it is also much larger.

Description. Holotype: Body length $14.5 \mathrm{~mm}$, black, convex. Pubescence black except for pronotum and elytra which are glabrous. Antennae black.

Head: Frons matte with very few punctures, each puncture with associated black setae. Clypeus granular with black setae.

Pronotum: Convex, matte with irregularly spaced punctures. No longitudinal smooth area. Distance between punctures is half to two times their width. Lateral margins curved, crenulate anteriorly becoming toothed posteriorly.

Elytra: Slightly wider medially than at base and apex. Striae deep with a few indistinct punctures. Interstriae matte with some punctures medially all along the length, punctures deep and separated by between one and three puncture widths, never touching striae.

Pygidium: Emarginate and somewhat punctate. Punctures spaced irregularly, sometimes touching or separated by up to three times the puncture width.

Metasternum: Fovea between the mesocoxae with a shorter one distally. Metasternal elevation ending in sharp angle and gradually sloping toward mesosternum. Area behind mesocoxae punctate.

Abdominal sternites: Smooth with indentations laterally.

Legs: Anterior femora punctate ventrally with black setae. Outside margin of anterior tibiae bearing small saw-like teeth proximally and four outward pointing teeth distally, each separated by five to eight saw-like denticles. Inside margin slightly curved inward with small tooth like projections and black setae along entire margin. Meso- and metafemora with median row of punctures and associated black setae. Mesotibiae with smooth inside margin and row of black setae; outer margin with two brushes of black setae in distal third. Vestigial second mesotibial spur absent. Metatibiae with black setae. All tarsomeres of metatarsi with setae, last tarsomere longest with claws half its length. This species is restricted to the Nama Karoo Biome.

Aedeagus: see Figure 6.

Etymology: The species name is derived from both its similarity to $S$. (S.) parvulus and its larger size.

Material examined: Holotype: \#M, Farm: Rooiput (30), S29.30289 E21.61613º 990m 1618.iii.2006, Davis \& Deschodt, TMSA. Paratypes: 7 specimens, unsexed, S.W.Afr., Namib, 
Ganab NE range, 23[ $\left.{ }^{\circ}\right] .08\left[^{\prime}\right] \mathrm{S}-15\left[^{\circ}\right] .36\left[^{\prime}\right] \mathrm{E}, 1.3 .1975$, E-Y:711, groundtrap: 90day, legEndrödy-Younga, TMSA, 2 specimens, unsexed, S.W.Afr., Namib, Ganab NE range, $23\left[^{\circ}\right] .08\left[^{\prime}\right] \mathrm{S}-15\left[^{\circ}\right] .36\left[^{\prime}\right] \mathrm{E}, 1.3 .1975$, E-Y:712, groundtrap: 90day, legEndrödy-Younga, TMSA, 6 specimens, unsexed, S.W.Afr., Namib, Ganab NE range, 23[ $\left[^{\circ}\right] .08\left[^{\text {'] }] \mathrm{S}-}\right.$ $15\left[^{\circ}\right] .36\left[^{'}\right] \mathrm{E}, 1.3 .1975, \mathrm{E}-\mathrm{Y}: 837$, groundtrap. 94day, legEndrödy-Younga, ground traps with ferm.banana bait, TMSA, 5 specimens, unsexed, S.W.Afr., c. Namib, Ganab N.E, Hillgap, $23\left[^{\circ}\right] .08\left[^{\prime}\right] \mathrm{S}-15\left[^{\circ}\right] .35\left[^{\prime}\right] \mathrm{E}, 7.7 .1978$, E-Y:711, groundtraps, 3years, leg. Endrödy-Younga, TMSA, 4 specimens, unsexed, S.W.Afr., Namib, Park SE corner, 23 [ $\left.{ }^{\circ}\right] .34\left[^{\prime}\right] \mathrm{S}-15\left[^{\circ}\right] .45\left[^{\prime}\right] \mathrm{E}$, 26.11.1974, E-Y:946, groundtraps. 105d, leg. Endrödy-Younga, TMSA, 1 specimen,

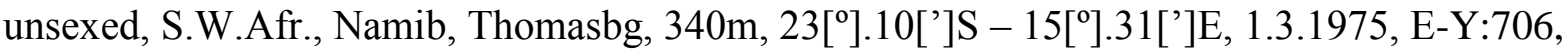
groundtrap. 97days, leg. Endrödy-Younga, TMSA, 1 specimen, unsexed, S.Afr., Namaqualand, Pofadder $100 \mathrm{kmW}, 29\left[^{\circ}\right] .22\left[^{\prime}\right] \mathrm{S}-18\left[^{\circ}\right] .37\left[^{\prime}\right] \mathrm{E}$, groundtraps. 62days, leg. Endrödy-Younga, ground traps with meat bait, TMSA, 5 specimens, unsexed, S.Afr.; W Cape, Katdoornkuil Farm, 32.70 $\left[^{\circ}\right]$ S - 22.75 $\left[^{\circ}\right]$ E, 3-6.XII.2007, leg.D.H.Jacobs, TMSA, 2 specimens, unsexed, FARM, WEISENBRON, SWA, (107 kms NW Aus via Farm Neisip) 5.II.1974, Davis \& Kirsten, SANC, 2 specimens, unsexed, AUS, SWA, (5 kms NE) 4.II.74, Davis \& Kirsten, SANC, 2 specimens, unsexed, AUS, SWA, (6/12 kms W) 4.II.74, SANC, 2 specimens, unsexed, GRUNAU, S.W.A., 6km N 24.II.85, H.H. Aschenborn, SANC, 1 specimen, unsexed, AUS, SWA, (South East) 13.II.74, Davis \& Kirsten, (1436) SANC, 10 specimens, unsexed, S.Afr., Cape-Karroo, Farm Zwartskraal, 33[ $\left.{ }^{\circ}\right] .10\left[{ }^{\prime}\right] \mathrm{S}-22\left[^{\circ}\right] .32\left[{ }^{\prime}\right] \mathrm{E}$, 8.11.1978,E-Y:1539a, groundtraps, 69days, leg.R.Oosthuizen, ground traps with meat bait,

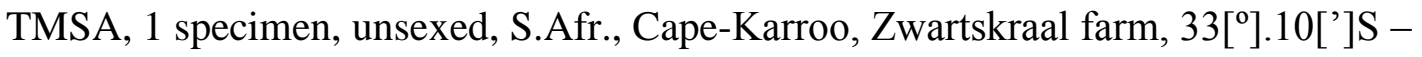
$22\left[^{\circ}\right] .32\left[^{\prime}\right] \mathrm{E}, 8.11 .1980, \mathrm{E}-\mathrm{Y}: 1736 \mathrm{a}$, groundtraps, 42days, leg.R.Oosthuizen, ground traps with

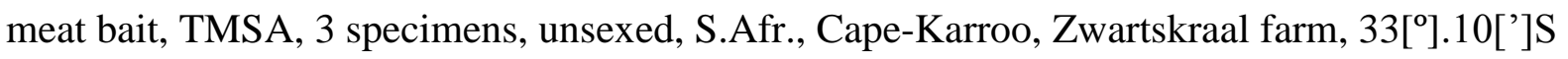
- 22[ [].32[']E, 8.11.1978,E-Y:1540a, groundtraps, 38days, leg. Endrödy-Younga, ground traps with faeces bait, TMSA, 5 specimens, unsexed, S.Afr., Cape-Karroo, Zwartskraal farm, $33\left[^{\circ}\right] .10\left[^{\prime}\right] \mathrm{S}-22\left[^{\circ}\right] .32\left[{ }^{\prime}\right] \mathrm{E}, 31.3 .1979, \mathrm{E}-\mathrm{Y}: 1567 \mathrm{a}$, groundtraps, 30days, leg. R.Oosthuizen, ground traps with faeces bait, TMSA, 24 specimens, unsexed, Farm Eufeesia (42), S30.933202 ${ }^{\circ}$ E 22.49185 ${ }^{\circ}$, 2006.03.08-10, Deschodt \& Strumpher, UPSA, 1 specimen, unsexed, Vreemdelingspoort., SE, 2415Dd., 22-I-1980, Univ. v. Pretoria, UPSA, 1 specimen, Farm:Deelpan,N-Cape, S29.56306E22.34164 ${ }^{\circ}$, A.Davis \& C.Deschodt, 19-21.iii.2003, UPSA, 1 specimen, unsexed, Farm: Springputs (17), S29.41316 ${ }^{\circ}$ E22.24810 ${ }^{\circ}$, 15-17.iii.2005 970m, Davis \& Deschodt, UPSA, 4 specimens, unsexed, Farm: Mariba (18), S29.67961 E22.06762 ${ }^{\circ}$, 18-20.iii.2005, Davis \& Deschodt, UPSA, 29 specimens, unsexed, Farm: Sonderpan (29), S29.22260 E21.77542 ${ }^{\circ}$ 1040m 16-18.iii.2006, Davis \& Deschodt, UPSA, 82 specimens, unsexed, same as holotype, 10 UPSA, 18 BMNH 18 MNHN 18 NHRS 18 SAMC.

\section{Scarabaeus (Scarabaeolus) niemandi Deschodt and Davis}

Figure 3, 6, 8 
Diagnosis. Scarabaeus (Scarabaeolus) niemandi is characterized by short black setae on the head and often punctate interstriae compared to brown setae on the head with interstriae that are smooth along their entire length in S. (S.) lucidulus. S. (S.) niemandi can be separated from Scarabaeus (Scarabaeolus) anderseni Waterhouse, 1890 by its larger size and black setae on the head compared to yellow setae on the head of $S$. (S.) anderseni. Punctation on the elytra of $S$. (S.) niemandi does not often open into the striae as in $S$. (S.) anderseni.

Description. Holotype: Body length $11.7 \mathrm{~mm}$, metallic green. Pubescence dark brown to black. Antennae yellow.

Head: Frons punctate, each puncture with associated short, stocky black setae. Smooth, puncture free mid-longitudinal area. Clypeus punctate with short stocky black setae.

Pronotum: Metallic green, punctate, space between punctures smooth, punctures separated by less than one puncture diameter, punctures with short stocky black associated setae. Longitudinal smooth area not extending to anterior edge of pronotum. Lateral margins curved, crenulate.

Elytra: Metallic green, lateral sides more or less parallel. Striae shallow with regular small punctures separated by less than two puncture diameters; punctures extending into margins of interstriae. Interstriae shiny with irregular punctures.

Pygidium: Emarginate and densely punctate, punctures small.

Metasternum: Long thin fovea between the mesocoxae, distally wider, with a shorter fovea more distally. Metasternal elevation ending with rounded angle and gradually sloping toward mesosternum. Area behind mesocoxae densely punctate, punctures small.

Abdominal sternites: Each sternite with row of punctures and associated dark setae anteriorly. Legs: Anterior femora shallowly punctate ventrally with black setae. Outside margin of anterior tibiae bearing small saw-like teeth proximally and four outward pointing teeth distally, each separated by six to eight saw-like denticles. Inside margin crenulate. Meso- and metafemora with median row of punctures and long fine dark brown setae. Inside margin of mesotibiae smooth with row of black setae, outside margin with two brushes of dark brown setae in distal third. Vestigial second mesotibial spur present. Metatibiae with black setae. All tarsomeres of metatarsi with black setae, last tarsomere longest with claws half its length.

Aedeagus: see Figure 6.

Etymology: This species is named in honour of Lukas Niemand who collected most of the type series of this species.

Material examined: Holotype: \#M, Soutpansberg, Limpopo, S22.87561 E29.73128 ${ }^{\circ}$, 3 -

4.ii.2009, L. J. Niemand, TMSA. Paratypes: 5 specimens, unsexed, same data as holotype. 2 
UPSA, 1 TMSA, 2 SANC. 1 specimen, unsexed, S.Afr.; Limpopo Prov., Mabote farm, 24[].07['] S 28[º]. 39['] E, 14.11.2009, leg.Ruth Müller, TMSA.

\section{Scarabaeus (Scarabaeolus) carniphilus Davis and Deschodt}

Figure 3, 6, 8

Diagnosis. Scarabaeus (Scarabaeolus) carniphilus can be separated from Scarabaeus (Scarabaeolus) andreaei Zur Strassen, 1963 by lacking the fine, but very dense and light brown setae on the elytra that characterize $S$. ( $S$.) andreaei. The punctures on the elytra of $S$. (S.) carniphilus are more random than those in Scarabaeus (Scarabaeolus) anderseni Waterhouse 1890, which are often opposite each other on adjacent interstriae to give the appearance of being two halves of the same puncture.

Description. Holotype: Body length $14.4 \mathrm{~mm}$, metallic green. Pubescence on legs brown, that on body light brown. Antennae orange.

Head: Frons matte with few punctures, each puncture with a central black seta. Median longitudinal carina present. Clypeus punctate with light brown setae.

Pronotum: Convex, matte and punctate. Very narrow longitudinal smooth line present. Punctures sometimes almost touching and sometimes half a puncture diameter apart. Lateral margins strongly curved, crenulate anteriorly, becoming smooth posteriorly.

Elytra: Slightly wider at base than at apex. Striae shallow, indistinct. Interstriae with punctures often overlapping creating rugose effect, punctures often open into striae.

Pygidium: Emarginate and punctate. Punctures dense and irregular, separated by less than one puncture width.

Metasternum: Shallow fovea between the mesocoxae with a shorter one distally. End of metasternal elevation rounded, almost right angled, steeply sloping toward mesosternum. Area behind mesocoxae with small densely spaced punctures. Abdominal sternites smooth with indentations laterally.

Legs: Anterior femora: thick at base, ventrally punctate with black setae. Outside margin of anterior tibiae bearing small saw-like teeth proximally and four sharp outward pointing teeth distally, each separated by seven to eight saw-like denticles. Inside margin slightly curved inward, slightly crenulate and with black setae along entire margin. Meso- and metafemora with median row of punctures and associated dark brown setae. Inside margin of mesotibiae smooth with row of black setae, outside margin with two brushes of black setae in distal 
third. Vestigial second mesotibial spur present. Metatibiae slightly curved inward with black setae. All tarsomeres of metatarsi with setae, last tarsomere longest with claws half its length.

Aedeagus: see Figure 6.

Etymology: S. (S.) carniphilus was only sampled by carrion-baited pitfall traps and not by traps baited with various dung types. It is, thus, named for this association.

Material examined: Holotype: \#M, Mabuasehube Game Reserve, SW Botswana, ii.2006, 2503'56,3”S 22001'56.8'E Tshikae \& Deschodt, TMSA. Paratypes: 8 specimens, unsexed, same data as holotype, 3 UPSA, 3 TMSA, 2 SANC; 1 specimen, 1012, VRYBURG, N.CP, (50 kms SW) 28.II.73, Bornemissza \& Temby, SANC.

\section{Scarabaeus (Scarabaeolus) planipennis Davis and Deschodt}

Figure 4, 6, 8

Diagnosis. Scarabaeus (Scarabaeolus) planipennis is quite distinct from other species within its geographical range. It can be separated from Scarabaeus (Scarabaeolus) flavicornis (Boheman, 1860) (also with flat elytra) by its muted greenish appearance and smaller size.

Description. Holotype: Body length $12.8 \mathrm{~mm}$, green. Pubescence is dark brown to black. Antennae yellow.

Head: Frons punctate, each puncture with associated short black setae. Wide puncture-free mid-longitudinal area. Clypeus punctate with short black setae.

Pronotum: Dark green and punctate with sparse short black setae. Spaces between punctures smooth comprising one to two puncture diameters. No longitudinal smooth area. Lateral margins curved, jagged anteriorly, with one side of jagged edge almost 10 times longer than the other gradually becoming toothed posteriorly.

Elytra: Dark green, lateral sides slightly curved slightly wider medially than at base and apex. Striae shallow with clear regular small punctures separated by about one puncture diameter. Interstriae very flat, matte, with very sparse small punctures.

Pygidium: Shallowly emarginate, matte.

Metasternum: No fovea between the mesocoxae. End of metasternal elevation rounded almost right angled and steeply sloping toward mesosternum. Area behind mesocoxae matte with small widely spaced punctures.

Abdominal sternites: Matte with short, fine black setae laterally. 


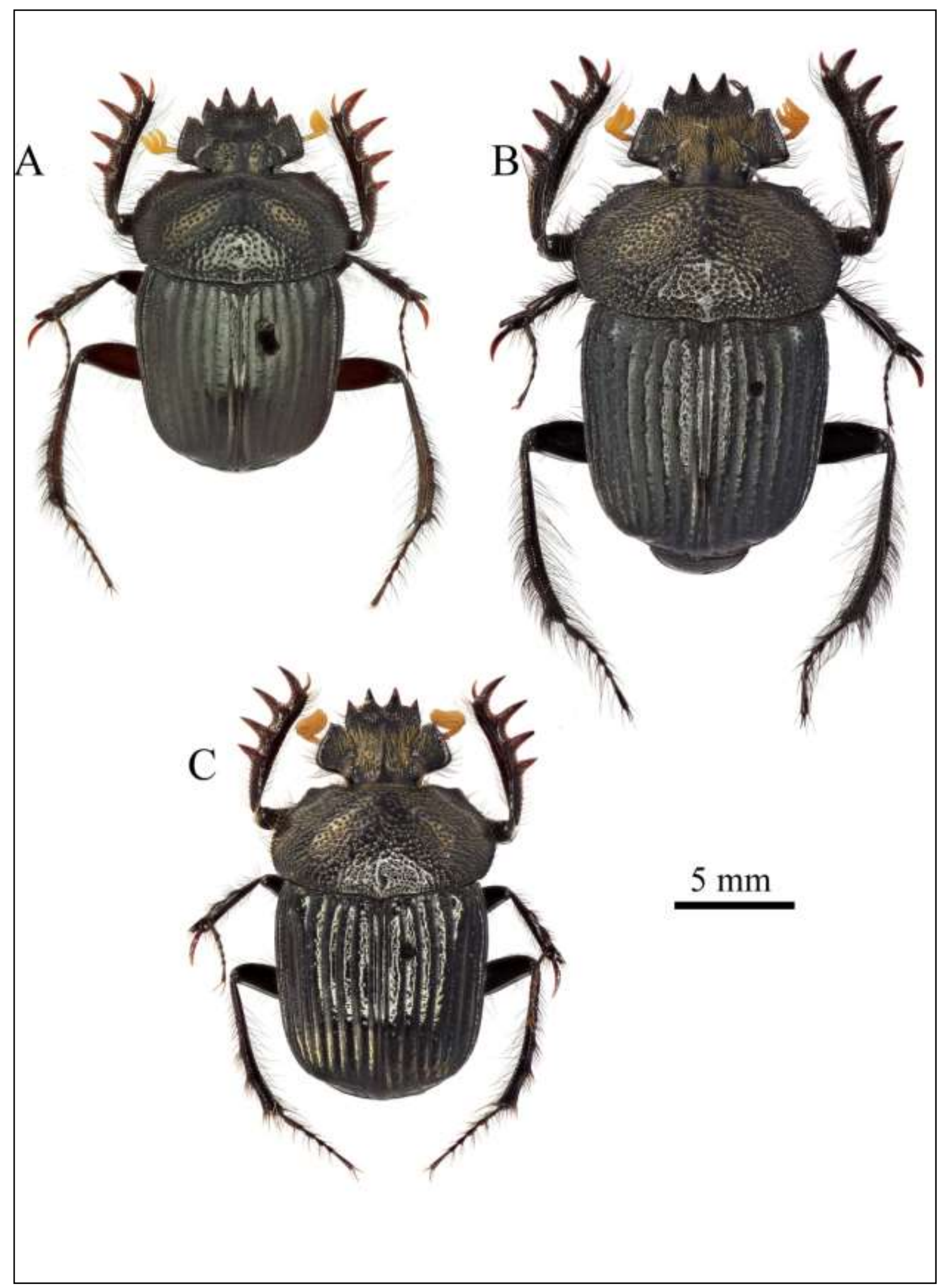

Figure 4. A. S. (S.) planipennis. B. S. (S.) ermienae. C. S. (S.) nitidus. 
Legs: Anterior femora swollen basally and shallowly punctate ventrally with black setae. Outside margin of anterior tibiae proximally crenulate merging into small saw-like teeth with four outward pointing teeth distally, each separted by nine to ten saw-like denticles. Inside margin finely crenulate, almost straight. Meso- and metafemora slender with irregular median row of punctures and fine black setae. Inside margin of mesotibiae smooth with row of black setae, outside margin with two brushes of black setae in distal third. Vestigial second mesotibial spur absent. Metatibiae curving slightly inward with black setae. All tarsomeres of metatarsi with setae, last tarsomere longest with claws almost half its length.

Aedeagus: see Figure 6.

Etymology: The species name is derived from the flat elytra.

Material examined: Holotype: \#M, Maputo Elephant Reserve, Mozambique,[15-18] xi.2006, $26^{\circ} 35^{\prime}$ '06.8'S 3246'45.1'E, sand, grassland, Escobar and Deschodt, TMSA. Paratypes: 15 specimens, unsexed, MOZAMBIQUE: Maputo Elephant Reserve, 10-16.xi.2007, 26³0'S 3251'E Pitfall Trap, W. Strumpher \& C. Deschodt, 2 UPSA, 5 TMSA, 5 BMNH, 3 SAMC, 1 specimen SOUTH AFRICA, KZN Pr. Tembe, 265'ㅇ 32²4'E, 7.iv.2004, J. v.d. Merwe, UPSA, 9 specimens Thembe Elephant Park, KZN ,South Africa, $27^{\circ} 01^{\prime}$ 'S 32 $24 \mathrm{E}, 24-$ 29.i.1996, B.J.Van Rensburg, 2UPSA, 7 SANC, 3 specimens South Africa: Kwazulu, Thembe Elephant Park, SE 2632 CD Ndumu, 7.x.1990, T. Beyers, UPSA, 1 specimen

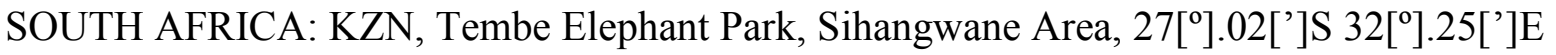
100m, 01.-04.ii.1996 R.Stals, SANC, 1 specimen, 2705 [Muzi, N. Natal, (26º52’32²3’'E), xxi.80, G. Vale.], SANC, 1 specimen, MUZI, TONGALAND, Natal (14 km W), (2652' 32²9’E), 4.xi.80, H.H. Aschenborn, SANC, 1 specimen, S. Afr : KrugerNat . PK, Punda

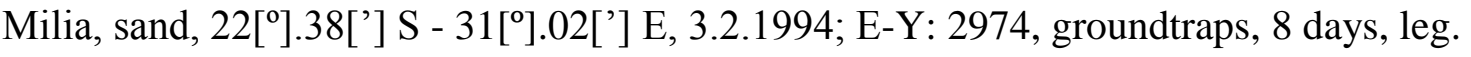
Endrödy-Younga, groundtraps with faeces bait, TMSA, 8 specimens, S. Afr : KrugerNat .

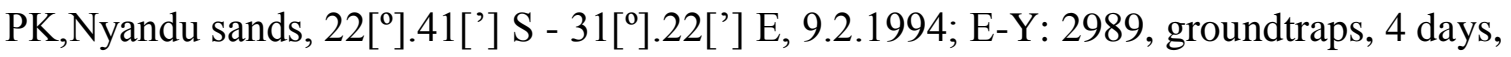
leg. Endrödy-Younga, groundtraps with faeces bait, 6 TMSA, 2 UPSA.

\section{Scarabaeus (Scarabaeolus) ermienae Deschodt and Davis}

Figure 4, 6, 8

Diagnosis. Scarabaeus (Scarabaeolus) ermienae can be separated from S. (S.) inoportunus by its metallic green colour and dense yellow setae on the pronotum. The metasternal elevation is more rounded and flattened whereas in $S$. (S.) inoportunus it is more angular. It can also be readily separated from $S$. (S.) damarensis by its metallic green colour and pronotal punctures that are much larger and closer together than in $S$. (S.) damarensis. The metasternal elevation is more rounded and setose in $S$. (S.) ermienae while in $S$. (S.) damarensis it makes a 90 degree angle toward the prosternum and is not setose on the metasternal elevation. S. (S.) ermienae is also easily separated from Scarabaeus 
(Scarabaeolus) gilleti Janssens 1940 which, similarly to S. (S.) damarensis, is black-bodied and shows a 90 degree angle at the metasternal elevation.

Description. Holotype: Body length $15.9 \mathrm{~mm}$, metallic green. Pubescence dark brown to black except on frons where it is yellow. Antennae yellow.

Head: Frons punctuate, each puncture with associated yellow setae. Mid-longitudinal area smooth, puncture free. Clypeus granular with yellow setae.

Pronotum: Metallic green and punctate, space between punctures smooth; punctures separated by less than one puncture diameter, each puncture with short yellow associated setae. No longitudinal smooth area. Lateral margins curved, crenulate anteriorly becoming more toothed posteriorly.

Elytra: Metallic green, lateral sides more or less parallel. Striae shallow with regular small punctures separated by less than two puncture diameters. Raised longitudinal median area of interstriae with irregularly shaped punctures, otherwise clear and smooth, longitudinal margins of interstriae mostly matte.

Pygidium: Emarginate and somewhat punctate, whole area matte. Punctures spaced irregularly, sometimes touching or separated by up to three times the puncture width.

Metasternum: Long thin fovea between the mesocoxae, distally wider, with a shorter fovea more distally. Metasternal elevation ending with rounded angle, gradually sloping toward mesosternum. Area behind mesocoxae punctate, punctures small.

Abdominal sternites: Covered with very fine setae, shallow punctures and shallow indentations laterally.

Legs: Anterior femora shallowly punctate ventrally with yellow to dark brown setae. Outside margin of anterior tibiae with small saw-like teeth proximally and four outward pointing teeth distally, each separated by five to six saw-like denticles. Inside margin crenulate, slightly curved inward at third outer tooth. Meso- and metafemora with irregular median row of punctures and long fine yellow setae. Inside margin of mesotibiae smooth with row of black setae, outside margin with two brushes of dark brown setae in distal third. Vestigial second mesotibial spur absent. Metatibiae with dark brown setae. All tarsomeres of metatarsi with setae, last tarsomere longest with claws half its length.

Aedeagus: see Figure 6.

Etymology: The species name is named in homage for Ermiena Deschodt, the wife of CMD.

Material examined: Holotype: \#M, Liuwa Plains Zambia, S14.645339 E022.624761 ${ }^{\circ}$ 2023.viii.2004 965m, Deschodt \& Groenewald, TMSA. Paratypes: 46 specimens, unsexed, 10 UPSA, 10 SANC, 10 TMSA, 4 BMNH, 4 MNHN, 4 NHRS, 4 SAMC, 3 specimens, unsexed 


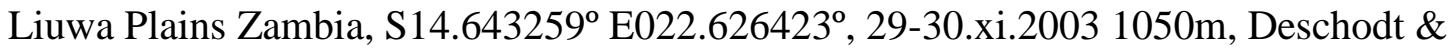
Groenewald, UPSA.

\section{Scarabaeus (Scarabaeolus) nitidus Davis and Deschodt}

Figure 4, 6, 8

Diagnosis. Scarabaeus (Scarabaeolus) nitidus can be separated from S. (S.) damarensis by its much shinier appearance and clearly punctate interstriae. The setae on the head are yellow in $S$. (S.) nitidus and dark brown in $S$. (S.) damarensis. Ventrally, S. (S.) nitidus has dense yellow pilosity whereas $S$. (S.) damarensis has less dense short dark brown setae.

Description. Holotype: Body length $13.5 \mathrm{~mm}$, metallic black. Pubescence yellow to dark brown. Antennae light brown.

Head: Frons somewhat punctate, each puncture with associated yellow setae. Midlongitudinal area smooth and puncture free. Clypeus punctate with sparse, short yellow setae.

Pronotum: Shiny black and punctate. Most punctures with short fine yellow setae, punctures sometimes overlapping but mostly separated by less than one puncture diameter, space between punctures smooth. Clear longitudinal smooth area, not extending to anterior edge of pronotum. Lateral margins curved, crenulate anteriorly becoming more toothed posteriorly.

Elytra: Shiny black, lateral sides slightly curved, slightly wider medially than at base and apex. Striae shallow with regular small punctures separated by less than two puncture diameters, punctures extending into interstriae. Interstriae shiny with some irregular punctures and short associated setae.

Pygidium: Shiny, emarginate with some small punctations.

Metasternum: Short wide fovea between the mesocoxae, with a shorter wide fovea more distally. Metasternal elevation ending with rounded angle and gradually sloping toward mesosternum. Area behind mesocoxae densely punctate, punctures small with dense long fine yellow setae.

Abdominal sternites: Raised, mostly smooth.

Legs: Anterior femora swollen at base, shallowly punctate ventrally with yellow setae. Outside margin of anterior tibiae with small saw-like teeth proximally and four outward pointing teeth distally, each separated by four to five saw-like denticles. Inside margin smooth, curving slightly inward. Meso- and metafemora with irregular median row of 
punctures and long fine yellow setae. Inside margin of mesotibiae smooth with row of dark brown setae, outside margin with two brushes of dark brown setae in distal third. Vestigial second mesotibial spur absent. Metatibiae:with dark brown setae. All tarsomeres of metatarsi with dark setae, last tarsomere longest with claws more than half its length.

Aedeagus: see Figure 6.

Etymology: The species is named for its shiny appearance.

Material examined: Holotype: \#M, Kutse Game Reserve BOT [Botswana], S23.44726 E24.39645 ${ }^{\circ}$, 25.i.2006, Tshikae \& Deschodt, TMSA. Paratypes: TMSA, 5 specimens, unsexed, 1 UPSA, 2 TMSA, 2 SANC, 1 specimen, Mabuasehube Game Reserve, SW

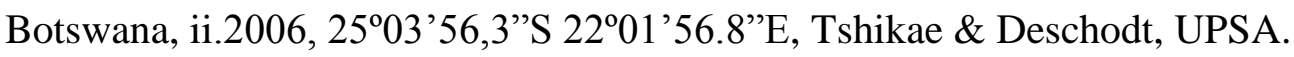

\section{Key to the known* species in the subgenus Scarabaeus (Scarabaeolus) Balthasar adapted from Zur Stassen 1967}

*The flightless Scarabaeus (Scarabaeolus) scholtzi Mostert and Holm 1982 is not included.

1 Interstriae of the elytra completely covered with large punctures that often open into stria forming ribbon-like patterns on interstriae, or smooth rectangular areas on elevated disk-like patches on interstriae, habitus always black ... 2

- Interstriae of the elytra smooth or with small punctures seldom opening into the striae, small dense pitting sometimes present close to the striae but never crossing the interstriae, habitus sometimes metallic green ... 12

2 Hind femora simple, without deep emargination proximally on posterior edge ... 3

-Hind femora deeply emarginated proximally on posterior edge $\ldots 8$

3 Dorsal surface of anterior tibiae without pointed humps at the base of the outer teeth ... 4

- Dorsal surface of anterior tibiae with a small pointed hump at the base of at least two of the outer teeth ...6

4 Striae of the elytra narrow, shallow, very finely granulated; interstriae only slightly convex, bearing large, flat, smooth, shiny, and square to rectangular raised sections interrupted by pits; raised sections not interconnected nor reaching the striae. Length 9-14mm. Deep sands, SW and S coasts; South Africa ... Scarabaeus (Scarabaeolus) intricatus (Fabricius 1801)

- Elytral striae wide, somewhat incised; interstriae somewhat arched with moderately large and deep round excavations regularly opening into striae, distribution mainly in Nama Karoo ... 5 
5 Antennae brown. Metasternal elevation with no large punctures proximally. Hind tibiae distally without angular bulges on outside. Raised interstriae smooth. Ventral edges of aedeagus straight, without angular bulging and without small teeth. Length 13-15mm. Nama Karoo; South Africa, S Namibia ... Scarabaeus (Scarabaeolus) pabulator Péringuey, 1908

- Antennae black. Metasternal elevation with a few large punctures proximally. Hind tibia distally with three angular bulges on outside, the two proximal ones continue as ridges. Raised interstriae shagreened. Ventral edges of aedeagus widened anteriorly, left paramere widening, forming a small tooth. Length 11-14mm. Nama Karoo; South Africa, S Namibia ... Scarabaeus (Scarabaeolus) karrooensis Zur Strassen 1961

6 Prothorax at base without a row of punctures. Interstriae with very shallow punctations, space between them only slightly elevated. The three proximal outer teeth of the front tibiae each with a pointed tooth-like protrusion at its base. Length $13 \mathrm{~mm}$. Arid SW Angola, NW Namibia ... Scarabaeus (Scarabaeolus) obsoletepunctatus Balthasar 1940

- Prothorax at base with a row of irregular dense punctures. Interstriae with deep punctations, space between them convex. Only the two proximal outer teeth of the front tibiae each with a pointed tooth-like protrusion at its base ... 7

7 Microgranulation in base of elytral pits not covering more than a quarter of the width of the interstriae. Sahel and dry savanna regions; W, N central and NE Africa; Senegal to Sudan ... Scarabaeus (Scarabaeolus) palemo Olivier 1789

- Microgranulation in base of elytral pits often covering more than a quarter of the width of the interstriae. Summer rainfall regions; Namibia, South Africa, Zimbabwe; Botswana (uncommon) ... Scarabaeus (Scarabaeolus) bohemani (Harold 1868)

8 Emargination proximally on posterior edge of hind femora smooth without hooks, sharp angles or denticles ... 9

- Emargination proximally on posterior edge of hind femora with hooks, sharp angles or denticles ... 11

9 Antennae black, no second emargination distally on posterior edge of hind femora. Deep sands of Mozambique Coastal Plain, S Mozambique, NE South Africa ... Scarabaeus (Scarabaeolus) gracai Ferreira 1952

- Antennae orange-brown, second emargination distally on posterior edge of hind femora ... 10

10 Distal emargination on posterior edge of hind femora with clear angular hook at inside. Mozambique Coastal Plain; S Mozambique, NE South Africa ... Scarabaeus (Scarabaeolus) clanceyi Ferreira 1954

- Distal emargination on posterior edge of hind femora rounded, no angular hook at inside.

Sand outlier at base of Soutpansberg, South Africa ... Scarabaeus (Scarabaeolus)

soutpansbergensis Deschodt and Davis spec. nov. 
11 Proximal emargination on posterior edge of hind femora not denticulate, terminating with sharp angles at both sides. Length $9-11 \mathrm{~mm}$. SE Kalahari deep sands and outliers (South Africa); Central Botswana ... Scarabaeus (Scarabaeolus) inquisitus Péringuey 1908

- Proximal emargination on posterior edge of hind femora denticulate, not terminating with sharp angles at both sides. Length 10-12mm. SW Kalahari deep sands; South Africa, Botswana, Namibia ... Scarabaeus (Scarabaeolus) kochi Ferreira 1952

12 Striae of the elytra deeply incised and conspicuously coarsely punctate, punctures wider than the striae ... 13

- Striae of the elytra only slightly incised, either not punctate or with only a few punctures, punctures not wider than the striae ... 18

13 Front corners of the prothorax conspicuously drawn forward to a point. Very small body size. Length 6-10mm. SW Kalahari, N Nama Karoo, edge of Namib Desert; South Africa, Namibia ... Scarabaeus (Scarabaeolus) parvulus Boheman 1860

- Front corners of the prothorax hardly drawn forward, obtuse angled ... 14

14 Body and antennae black. Upper Karoo, South Africa; S Namibia uplands ... Scarabaeus (Scarabaeolus) megaparvulus Davis and Deschodt spec. nov.

- Upper side of body with green or blue metallic lustre. Antennae yellow to orange brown ... 15

15 Only the $7^{\text {th }}$ interstriae of the elytra in basal half have a few large punctures; the other interstriae smooth, without punctures. Length: 9-12mm. North of S Kalahari deep sands, outliers to east; South Africa, Botswana, Namibia ... Scarabaeus (Scarabaeolus) lucidulus (Boheman) 1860

- All interstriae of the elytra in basal half with several punctures, which partially coalesce with punctures of the same size on the striae ... 16

16 Setae on head black, short. Sand outliers near Soutpansberg and Waterberg, South Africa ... Scarabaeus (Scarabaeolus) niemandi Deschodt and Davis spec. nov.

- Setae on head orange to brown, long ... 17

17 Punctures on elytra fine, punctures on interstriae not much wider than interstriae. Interstriae of elytra with dense setae. Length: 11-14mm. SW Kalahari deep sands; South Africa, Botswana ... Scarabaeus (Scarabaeolus) carniphilus Davis and Deschodt spec. nov. - Punctures on elytra coarse, punctures on interstriae not much wider than interstriae. Interstriae of elytra only with sparse setae. Length: 8-10mm. S Kalahari, sand outliers to east, central Namib Desert; South Africa, Botswana, Namibia ... Scarabaeus (Scarabaeolus) anderseni Waterhouse 1890 ... 20

18 Elytra black, sometimes with a greenish, bluish or bronze metallic lustre ... 19 
- Elytra reddish yellow or reddish-brown ... 31

19 Sternite V of male with a small granule in the middle just in front of the rear edge. SW coast, Somalia ... Scarabaeus (Scarabaeolus) laevifrons Fairmare 1884

-Sternite $\mathrm{V}$ of male simple, without granules in front of posterior edge ... 20

20 Habitus green or muted green... 21

- Habitus black ... 23

21 Elytral interstriae flat, not raised, elytra not prominently striated. Deep sands of Mozambique Coastal Plain, S Mozambique, NE South Africa ... Scarabaeus (Scarabaeolus) planipennis Davis and Deschodt spec. nov.

- Elytral interstriae ribbed or raised, elytra clearly striated ... 22

22 Punctation of prothorax fine. Deep sands of Mozambique Coastal Plain, S Mozambique, NE South Africa ... Scarabaeus (Scarabaeolus) andreaei Zur Strassen 1963

- Punctation of prothorax coarse. Deep Kalahari sands; SW Zambia ... Scarabaeus (Scarabaeolus) ermienae Deschodt and Davis spec. nov.

23 Elytral interstriae smooth and flat, elytra not prominently striated. Kalahari deep sands, outliers to east, Central Namib Desert, SW coast; South Africa, Namibia, Botswana, Zambia ... Scarabaeus (Scarabaeolus) flavicornis (Boheman 1860)

- Elytral interstriae raised, elytra conspicuously striated ... 24

$24 \mathrm{Up}$ to $16 \mathrm{~mm}$ in length ... 25

- Longer than $17 \mathrm{~mm} \ldots 29$

25 Interstriae of elytra with conspicuous punctures ... 26

- Interstriae of elytra without punctures ... 27

26 Interstriae of elytra appearing dull. SW Kalahari deep sands; South Africa, Botswana, Namibia ... Scarabaeus (Scarabaeolus) inoportunus Ferreira 1953

- Interstriae of elytra brightly shining. SW Kalahari deep sands, Botswana ... Scarabaeus (Scarabaeolus) nitidus Davis and Deschodt spec. nov.

27 Hair on the head and pronotum black. Antennal colour-orange brown. Inside of front tibiae somewhat serrated. Central Mega-Kalahari; Angola ... Scarabaeus (Scarabaeolus) gilleti Janssens 1940

- Hair on the head and pronotum yellowish. Antennal colour yellow. Inside of front tibiae finely serrated ... 28 
28 Punctation on pronotum fairly dense, punctures close together. S Kalahari deep sands; Namibia, Botswana, South Africa ... Scarabaeus (Scarabaeolus) damarensis Janssens 1940

- Punctation on pronotum more dispersed. NE Mega-Kalahari; Congo (DRC) ... Scarabaeus (Scarabaeolus) kwiluensis Janssens 1940

29 Puncture-free centre line of the prothorax hardly raised; elytra simply striated, not ribbed, interstriae uniformly curved with wide matte area, centre line silky mat. Deep West coastal sands, South Africa (Northern and Western Cape Province) ... Scarabaeus (Scarabaeolus) reichei Waterhouse 1890

- Puncture-free centre line of the prothorax narrow and clearly raised; elytra ribbed, interstices slightly curved, interstriae narrowly matte along lateral edges, central ribs clear. Inland of Western South Africa and Southern Namibia ... 30

30 Antennae and dorsal setae black. Sand pans and dunes, South Africa (Free State, Western and Northern Cape Province), Southern Namibia ... Scarabaeus (Scarabaeolus) fritschi Harold 1868

- Antennae and setae entirely orange. Namibia (inland edge of Namib Desert) ... Scarabaeus (Scarabaeolus) canaliculatus Fairmaire 1888.

31 Ventral, distal edge of fore femora with a large tooth. Edge of the pygidium strongly emarginate. Length: 13-17 mm. Namib Desert Dune Fields, SW Namibia, NW South Africa ... Scarabaeus (Scarabaeolus) rubripennis (Boheman 1860)

- Ventral, distal edge of fore femora without tooth. Edge of the pygidium simple. Length: 910 mm. Arid coast; SW Angola, NW Namibia ... Scarabaeus (Scarabaeolus) knobeli Ferreira 1958

\section{Notes on some of the currently valid species}

Scarabaeus (Scarabaeolus) palemo Olivier 1789 and Scarabaeus (Scarabaeolus) bohemani (Harold 1868), Figure 5, 10.

Depending on the author, these two species have been classified either as valid taxa or as synonyms. Early authors first described Scarabaeus palemo Olivier 1789, citing a wide distribution from "Sénégal au Cap de Bonne-Espérance" [Senegal to the Cape of Good Hope] and then Ateuchus (Sebasteos) cicatricosus Boheman 1857, citing a regional distribution in "Caffraria tota" [all of southeast South Africa or, perhaps, all of southern Africa]. Harold (1868) subsequently identified A. cicatricosus Boheman as a pre-occupied name and renamed the species as Ateuchus bohemani. After transfer of this Ateuchus species to Scarabaeus, later authors cited S. bohemani as a synonym of S. palemo (Péringuey 1901, Janssens 1940, Ferreira 1953, zur Strassen 1961). However, zur Strassen (1967) raised S. bohemani back to valid species status separate from $S$. palemo. 
As opinion has clearly differed over time, and type localities (Olivier 1789, Boheman 1857) suggest overlapping ranges between the two species in southern Africa, we have examined morphological differences between specimens from different localities. In southern Africa,

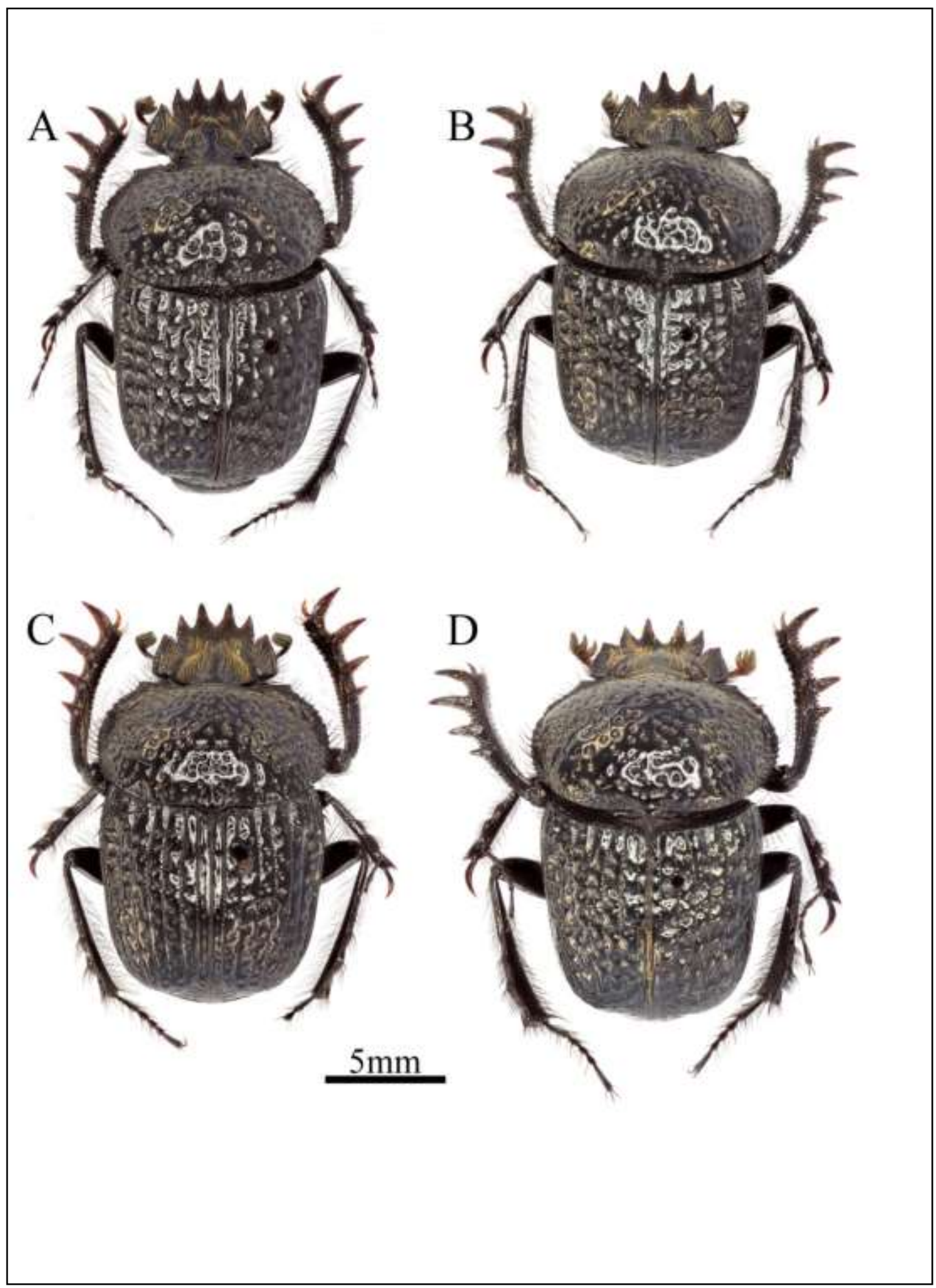

Figure 5. S. (S.) bohemani from: A. Hoheacht (24.40[ $\left.\left[^{\circ}\right] \mathrm{S} 16.23\left[^{\circ}\right] \mathrm{E}\right)$ (TMSA). B. North of Soutpansberg $\left(\mathrm{S} 22.87561^{\circ} \mathrm{E} 29.73128^{\circ}\right)(\mathrm{UPSA})$. C. Britstown $\left(30.51124^{\circ} \mathrm{S} 23.51983^{\circ} \mathrm{E}\right)$ (UPSA). D. S. (S.) palemo from Ghana, Damongo (N 904' W 148') (TMSA). 
there is a southeast to northwest geographical cline in interstrial macro-sculpture on the elytra of $S$. (S.) bohemani. Specimens from the Upper Karoo of South Africa (Britstown) bear large punctures on the elytra with clear basal micro-granulation. Specimens to the north (Soutpansberg) show similar basal micro-granulation but the pits are smaller. Specimens

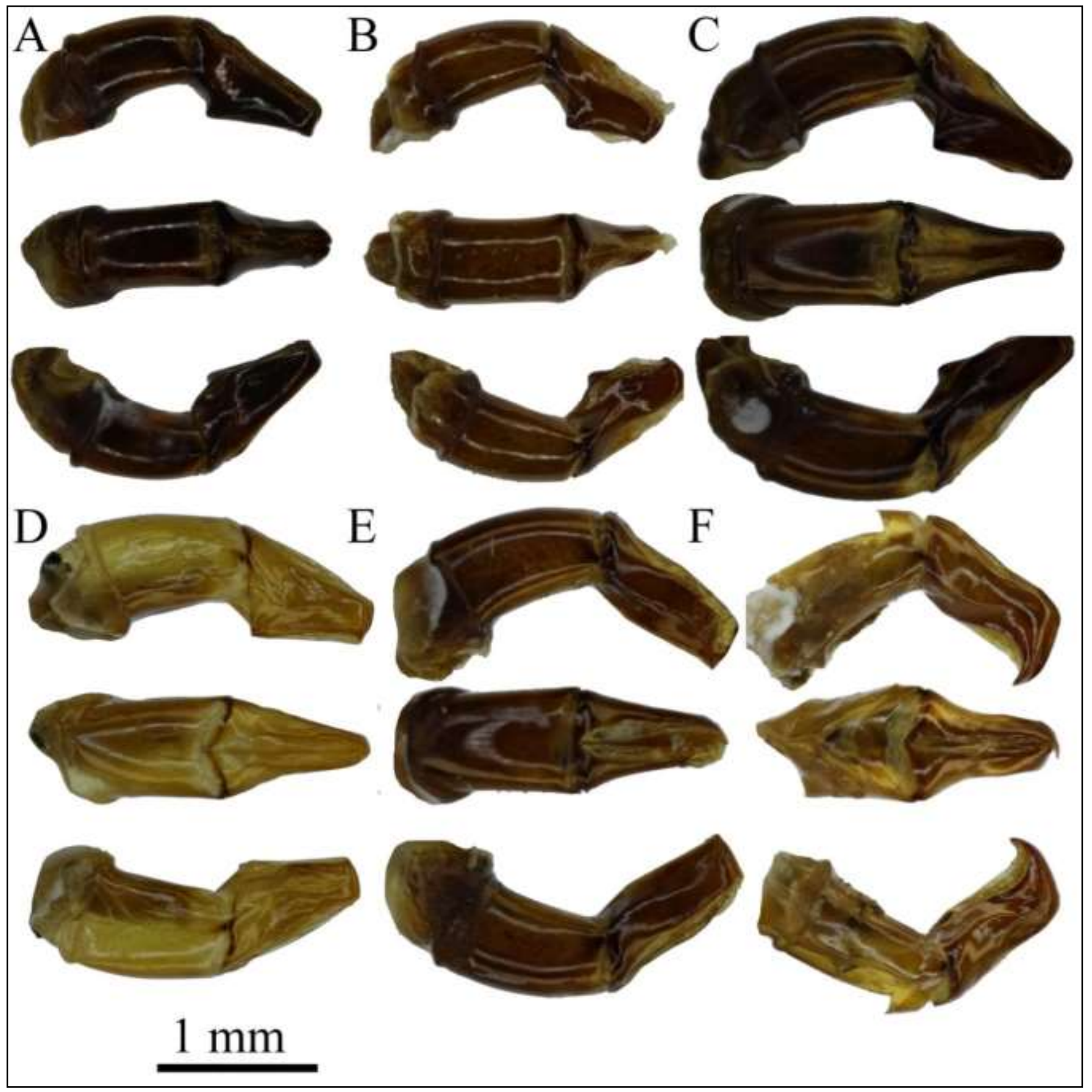

Figure 6. Aedeagi of: A. S. (S.) megaparvulus. B. S. (S.) niemandi. C. S. (S.) carniphilus. D. S. (S.) ermienae. E. S. (S.) planipennis. F. S. (S.) nitidus. From top to bottom, photographs of aedeagi are of the left, dorsal and right view for each species. 


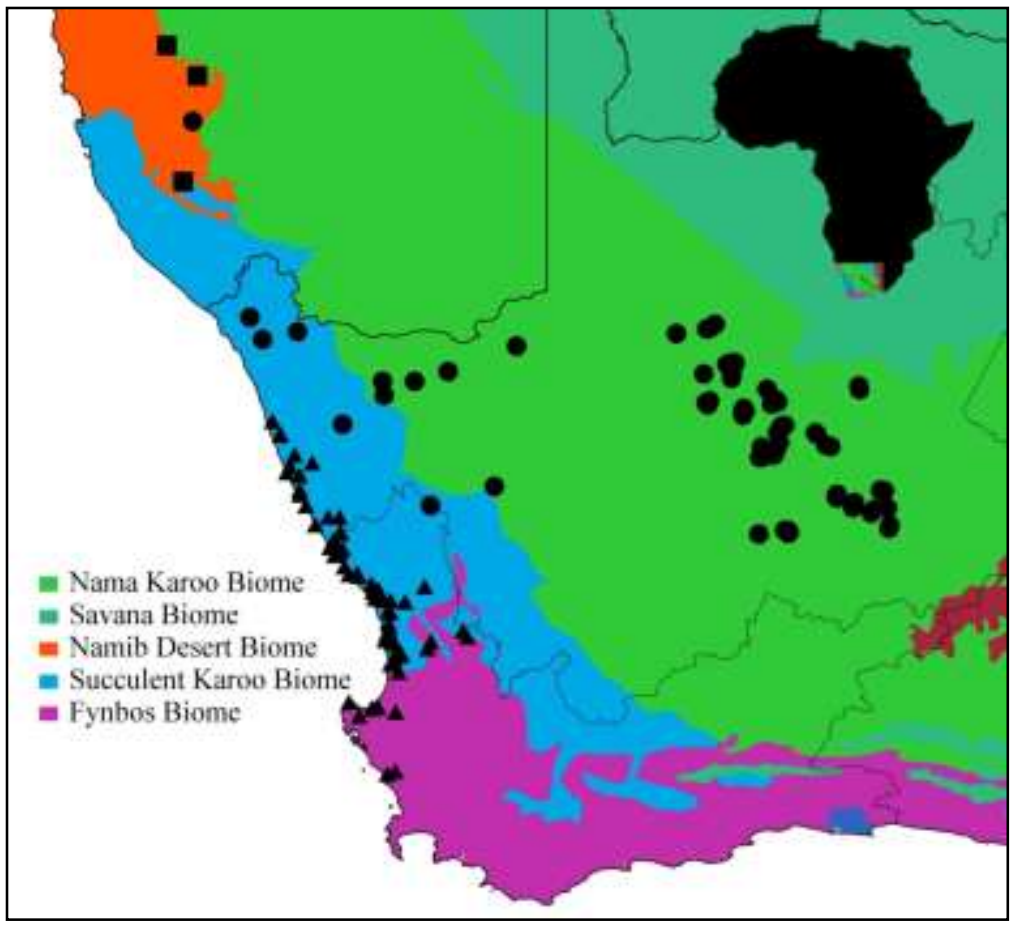

Figure 7. Map showing the collecting localities of specimens of ( $\square$ ) S. (S.) canaliculatus, (O) S. (S.) fritschi and $(\mathbf{\Delta}) S$. (S.) reichei in SANC, TMSA and UPSA collections.

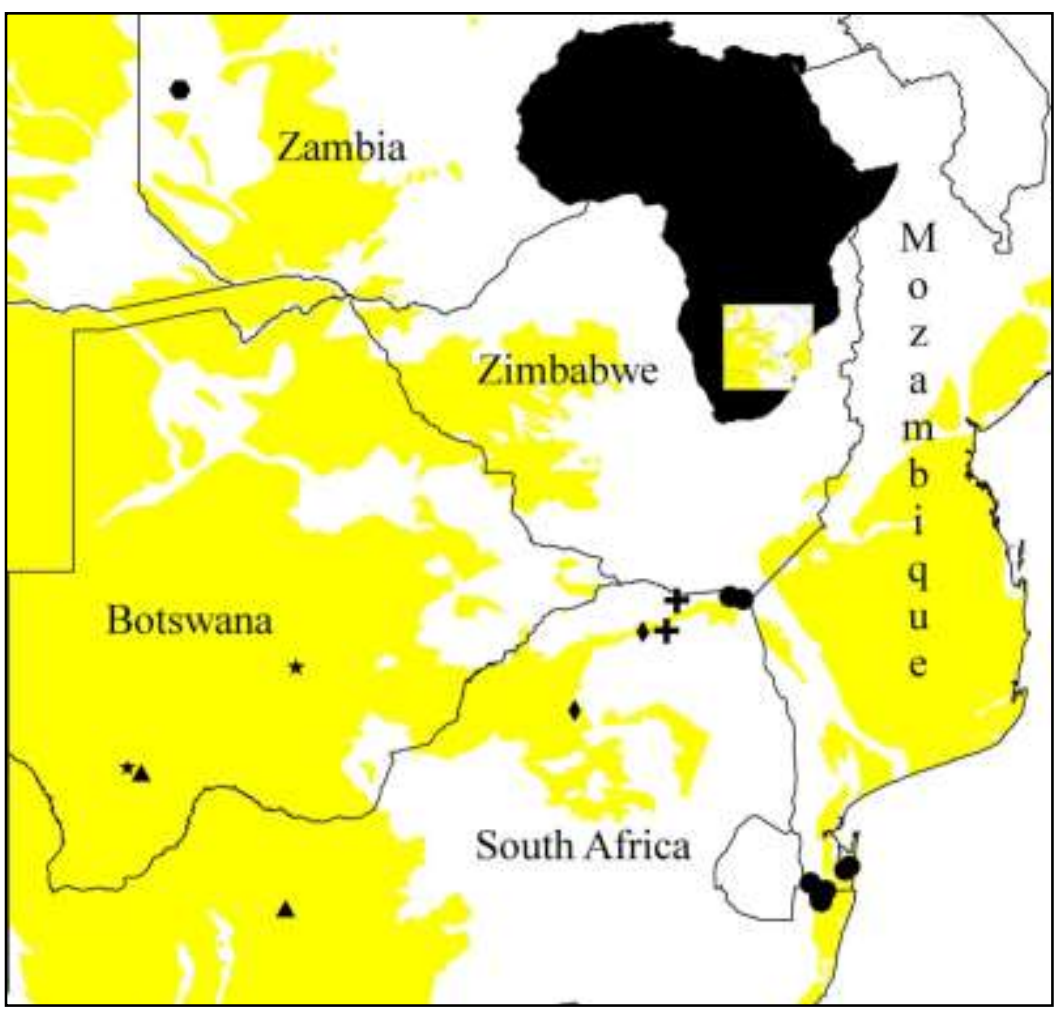

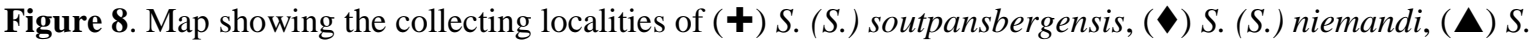
(S.) carniphilus, (-) S. (S.) ermienae, (○) S. (S.) planipennis and ( $\star$ ) S. (S.) nitidus. The yellow highlighted areas show the distribution of Arenosols (Soils that appear to be without any profile development other than an A horizon which consists mostly of unconsolidated sand deposits). Source: FAO digital soil map of the world (FAO/IIASA/ISRIC/ISSCAS/JRC2012). 


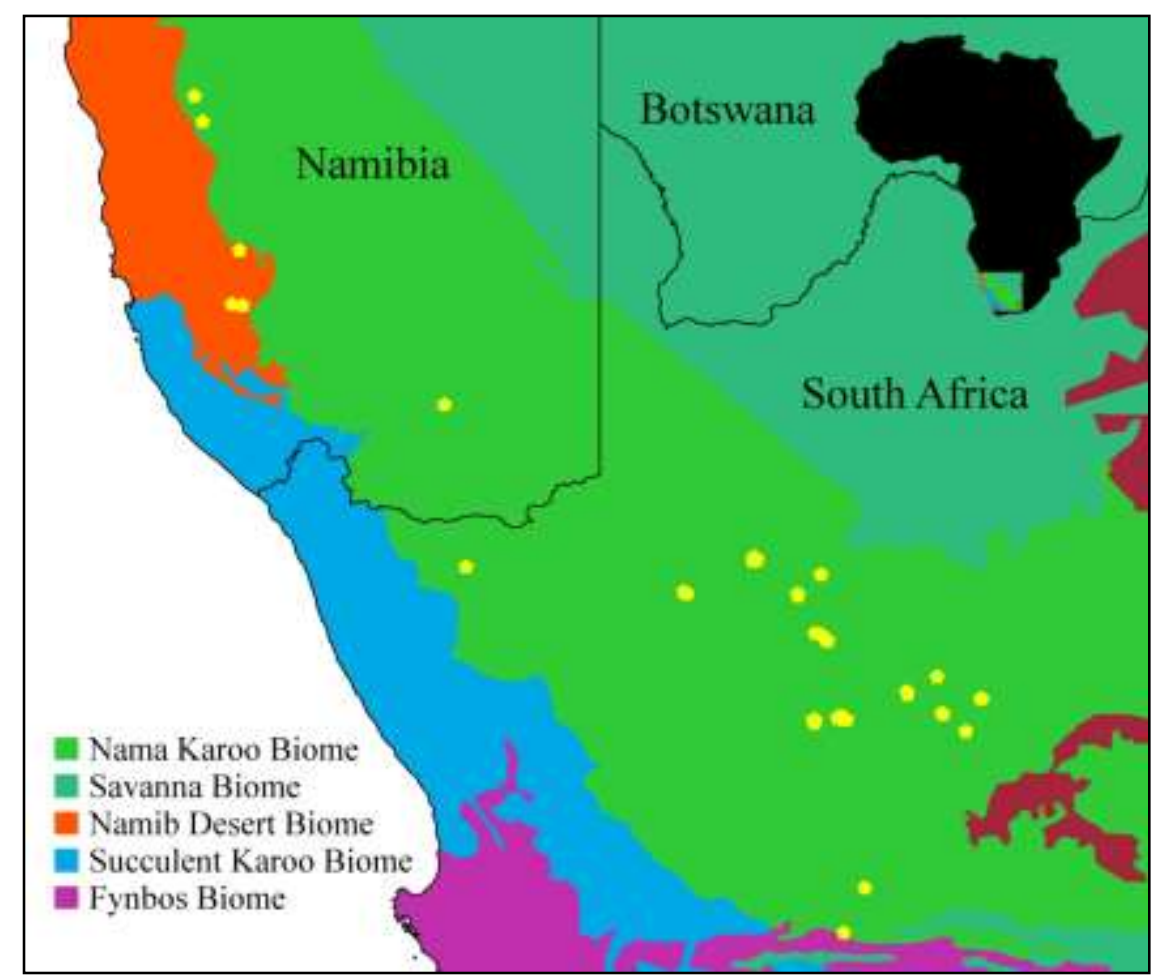

Figure 9. Map showing the collecting localities of $S$. (S.) megaparvulus within the Nama Karoo Biome.

from the Namib Desert region of Namibia (Hoheacht) have even smaller pits, no visible micro-granulation at macro-scale, and approach the condition of virtually effaced pitting in the larger-bodied Scarabaeus (Scarabaeolus) obsoletepunctatus Balthasar 1940 that is found primarily in arid Southwest Angola. Specimens of $S$. (S.) palemo Olivier from Ghana also lack visible micro-granulation from the base of the pits at macro-scale. Furthermore, the inner margin of the front tibiae shows proximally-pointing, cone-like projections in Britstown and Soutpansberg $S$. (S.) bohemani. However, the small cone-like or triangle-like projections point inward in Hoheacht $S$. (S.) bohemani and Ghanaian S. (S.) palemo.

Although geographical variation in macro-sculpture suggests a species complex, electron micrographs (Fig. 10) show that the bases of large or smaller pits in all individuals bear strong or weak microgranulation thus eliminating a major presence or absence character used to separate $S$. (S.) bohemani from $S$. (S.) palemo by zur Strassen (1967). The other character regarding denticles on the fore tibia is asymmetrically represented across examined material of the two species. In view of the morphological and distributional evidence, we feel that it would be justified to, again, synonymize $S$. (S.) bohemani with $S$. (S.) palemo. However, any final decision would best be supported using molecular techniques. It would also be useful to simultaneously evaluate the status of $S$. (S.) obsoletepunctatus. 


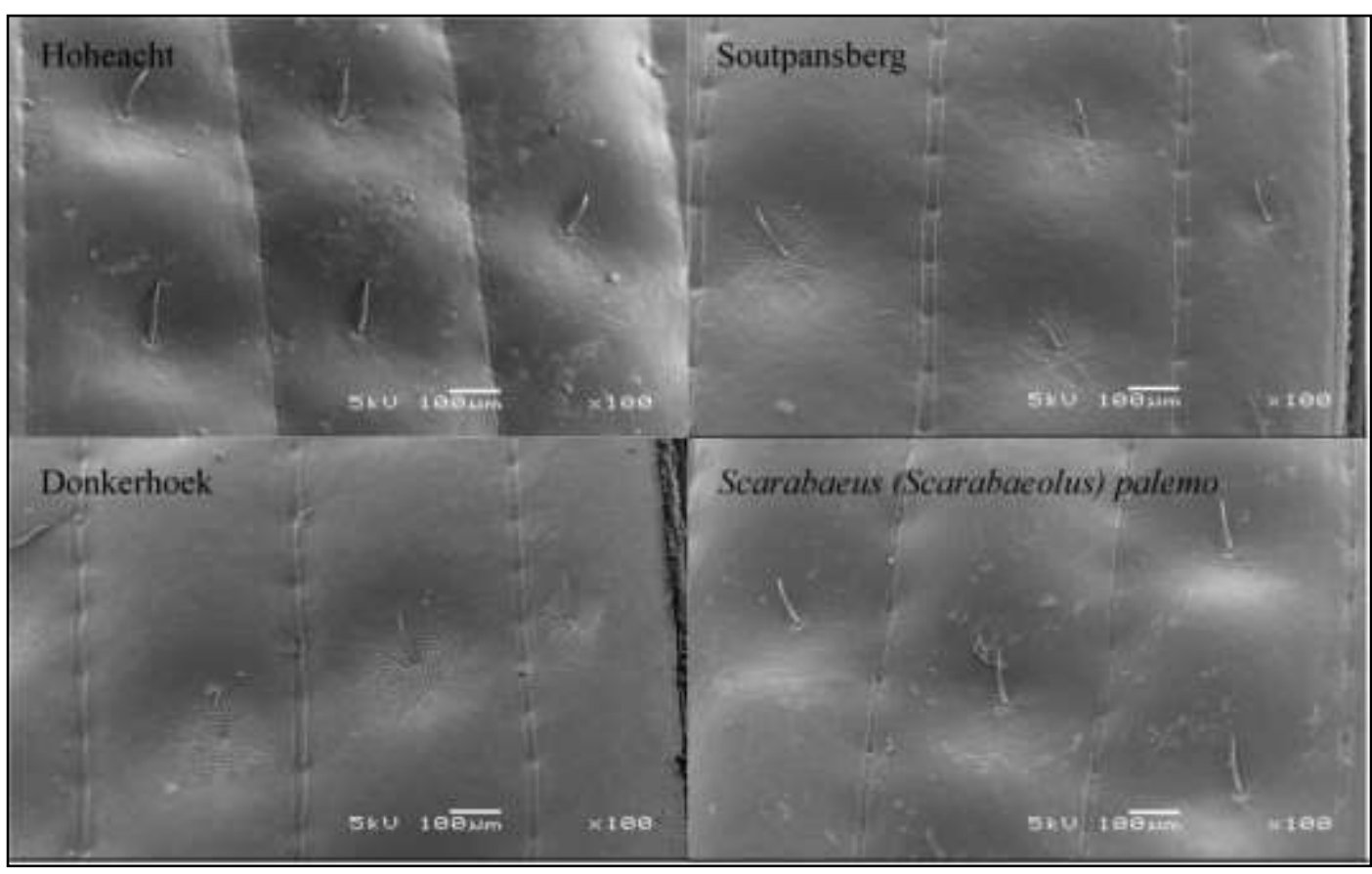

Figure 10. Electron micro-graphs showing the microgranulation that is present in the elytral pits of $S$. (S.) bohemani and $S$. (S.) palemo.

\section{Scarabaeus (Scarabaeolus) gracai Ferreira 1952}

The holotype is on permanent loan from Museu Dr. Álvaro de Castro, Lourenço Marques (Maputo, Mozambique) in the TMSA.

Scarabaeus (Scarabaeolus) anderseni Waterhouse, 1890

Although the locality label with the type specimen (Fig. 11) reads as "Lake Ngami" [20³0'S $22^{\circ} 45^{\prime} \mathrm{E}$ ], the type locality was cited as “Lake Nyassa" [11 ${ }^{\circ} 45^{\prime} \mathrm{S} 34^{\circ} 30^{\prime} \mathrm{E}$ ] (Waterhouse 1890). The reasons for this error are unknown to us. The type was collected by Karl Johan Andersson, a naturalist and explorer who never went near Lake Nyassa (Péringuey 1901) but who did undertake an expedition from Walvis Bay that reached Lake Ngami in 1853 (Andersson 1875). In a listing of collectors (Johnston 1903), we were unable to locate any information on the "Andersen" for whom the species was apparently named, neither to confirm his identity nor to determine if he sampled at Lake Nyassa [Lake Malawi]. 


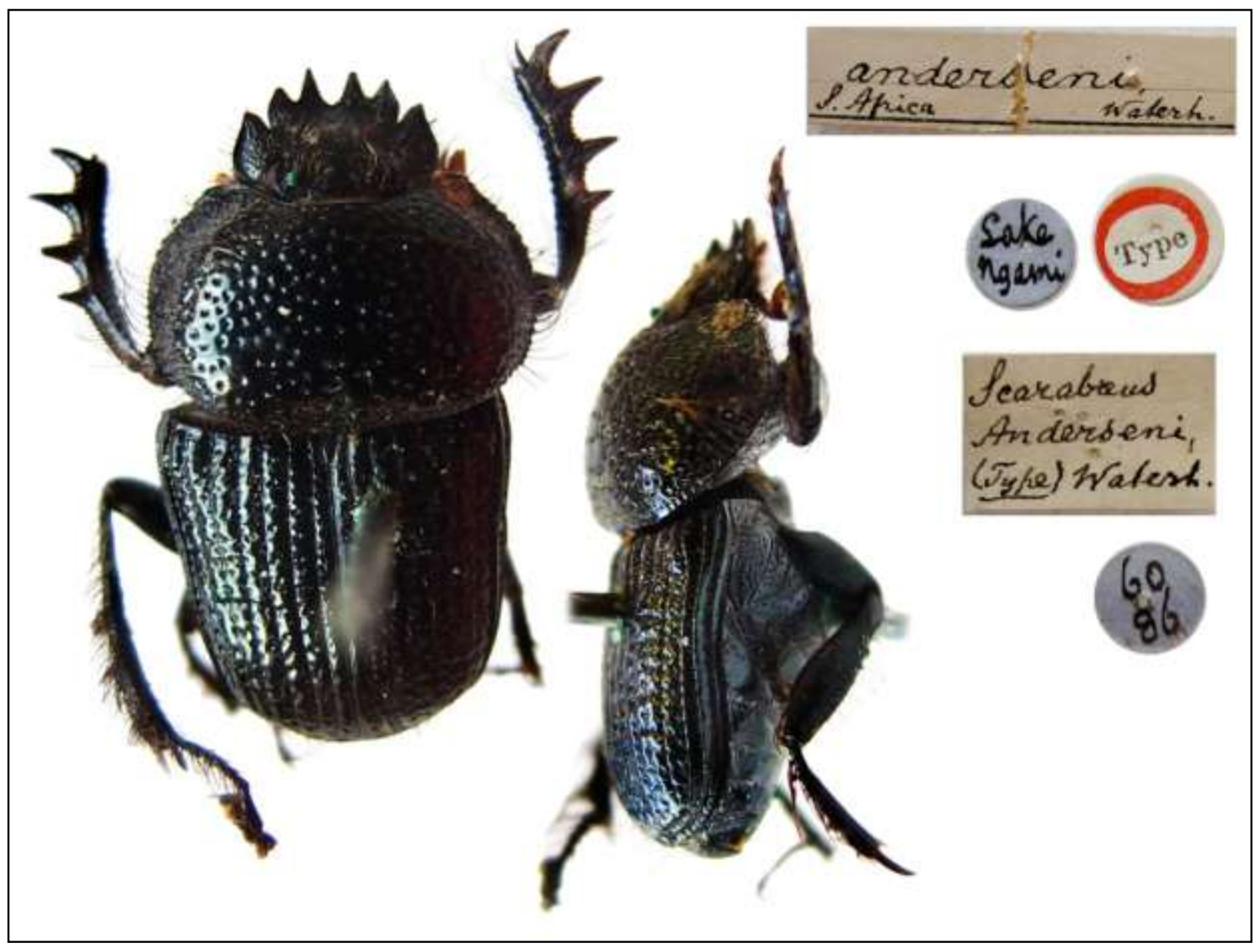

Figure 11. Photographs of the type of $S$. (S.) anderseni with its labels.

Scarabaeus (Scarabaeolus) lucidulus (Boheman) 1860

This species has a widespread distribution in South Africa, Zimbabwe, Botswana and Namibia. However we could not see any notable difference between specimens from

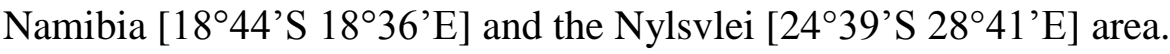

\section{Scarabaeus (Scarabaeolus) flavicornis (Boheman 1860)}

The recorded range of this species is from Lamberts Bay [32 $5^{\prime} \mathrm{S} 18^{\circ} 19^{\prime} \mathrm{E}$ ] in the south

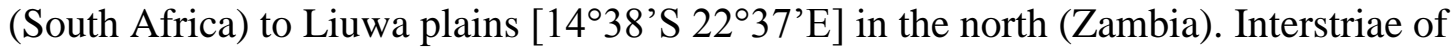

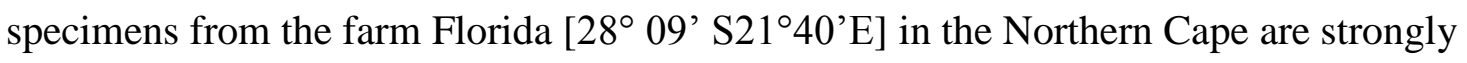
shagreened along the edge of the striae, giving them a dull appearance (Fig. 12). In contrast, specimens from the Liuwa Plains are very smooth and relatively shiny (Fig. 12). We believe that this is merely a cline as a specimen seen from Karibib [21 ${ }^{\circ} 56^{\prime} \mathrm{S} 15^{\circ} 51^{\prime} \mathrm{E}$ ] (Namibia) shows intermediate sculpture (Fig. 12). There is very little difference between aedeagi from Zambian and Northern Cape specimens. 


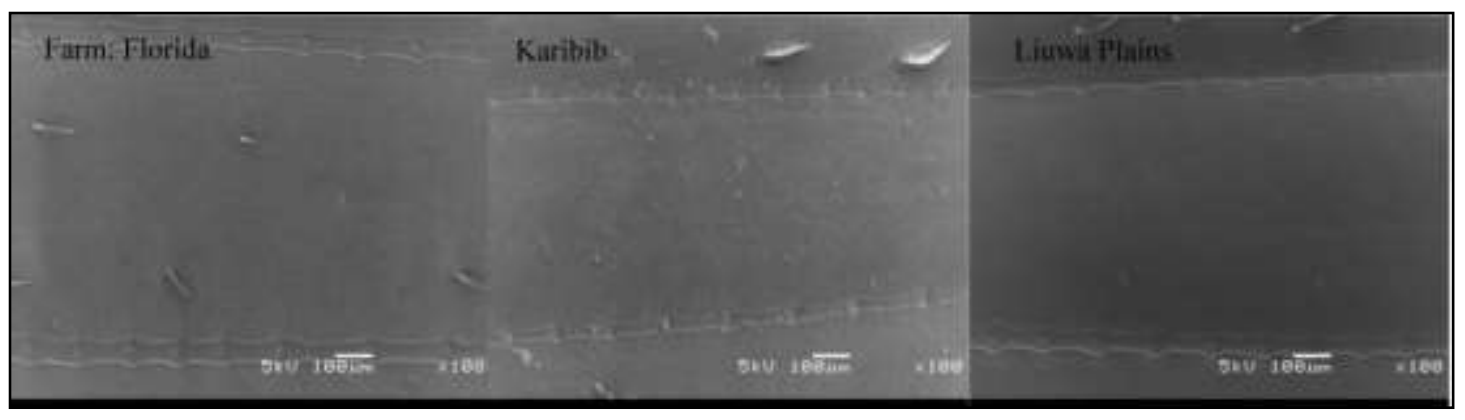

Figure 12. Electron micro-graphs showing the microgranulation that is present in the elytral interstriae of $S$. (S.) flavicornis from the Farm Florida, Karibib and Liuwa Plains.

Scarabaeus (Scarabaeolus) gilleti Janssens 1940

The locality label on the type specimen reads "Bite Angola" = Bita very close to Luanda (W. Dekoninck, Personal Communication). S. (S.) damarensis Janssens 1940, S. (S.) gilleti and $S$. (S.) kwiluensis Janssens 1940 are a group of closely related species with distributions centred, respectively, from south to north across the Mega-Kalahari deep sands between northern South Africa and eastern Congo (DRC).

\section{Scarabaeus (Scarabaeolus) scholtzi Mostert \& Holm 1982}

This species is only included in Scarabaeolus on the presence of the second mesotibial spur (Mostert \& Holm 1982). Forgie et al (2005) proposed to move it to Scarabaeus (Scarabaeus) as it consistently falls outside their "Scarabaeolus clades".

\section{Acknowledgements}

Ruth Muller (TMSA) and Riaan Stals (SANC) are thanked for the loan of specimens. Simon Van Noordt (SAMC), Johannes Bergsten (NHRS), Jiri Zidek, Antoine Mantilleri (MNHN) and Helena Maratheftis (BMNH) are thanked for sending photographs of types. Paul Schoolmeesters is thanked for sending taxonomic papers from his extensive collection. Copyright for the photographs used in Figure 2 is with MNHN for $S$. ( $S$.) canaliculatus and with BMNH for $S$. (S.) reichei. Copyright for the photographs used in Figure 11 is also with BMNH. We wish to gratefully acknowledge the JRS Biodiversity Foundation for funding the project that led to the recognition of the taxonomic issues addressed in this paper

\section{References}

Andersson, C.J. (1867) Lake Ngami: or, Explorations and discoveries, during four years' wanderings in wilds of south-western Africa. Struik, Cape Town, 521 pp. 
Balthasar, V. (1940) Einige neue Scarabaeiden-Arten. Casopis Ceskoslovenske Spolecnosti Entomologicke, 37 (3-4), 67-76.

Balthasar, V. (1965) Eine neue Undergattung und neue Arten der Familie Scarabaeidae (Col). (121. Beitrag zur Kenntnis der Scarabaeoidea). Acta entomologica bohemoslovaca, 62 (1), $14-23$.

Boheman, C.H. (1860) Coleoptera Caffraria annis 1838-1845 a J. A. Wahlberg collecta. Öfversigt Kongliga Svenska Vetenskapsakademiens Förhandlingar, 17 (3), 107-120.

Fabricius, J.C. (1801) Systema Eleutheratorum secundum ordines, genera, species: adiectis synonymis, locis, observationibus, descriptionibus. Tomus I Impensis bibliopoli academici novi, Kiliae, 506 pp.

Fairmaire, L.M.H. (1884) Diagnoses des Coléoptères de l'Afrique orientale (Suite). Annales de la Societe entomologique de Belgique. Comptes Rendus des seances Bruxelles, 28, 121125 (cxxi-cxxv).

Fairmaire, L.M.H. (1888) Enumération des Coléoptères recueillis par M. le Dr. Hans Schinz dans le Sud de l'Afrique. Annales de la Société entomologique de France. 6 (8), 173-202.

FAO/IIASA/ISRIC/ISSCAS/JRC (2012) Harmonized world soil database (version 1.21). FAO, Rome, Italy and IIASA, Laxenburg, Austria. ESRI shapefile downloaded from http://www.fao.org/geonetwork/srv/en/metadata.show?id=14116, last accessed 18 August 2014.

Ferreira, M.C. (1952) A new species of Scarabaeus. Annals of the Transvaal Museum. 22 (1), $73-77$.

Ferreira, M.C. (1953) Contribuicao para o estudo dos Escarabaeideos da Africa do Sul. Memorias Museum Dr. Alvaro de Castro. (2), 23-26.

Ferreira, M.C. (1954) Some Scarabaeina in the Durban Museum and Art Gallery. Durban Museum Novitates. 4 (7), 91-95.

Ferreira, M.C. (1958) A new species of Scarabaeus from South West Africa. Novos Taxa Entomológicos. 5, 3-4.

Ferreira, M.C. (1968) Contribuicao para o estudo dos Escarabideos de Moçambique. Descriçao de uma espécie nova do subgénero Scarabaeolus Balthasar. Novos Taxa Entomológicos. 58, 3-9.

Ferreira, M.C. (1972) Os escarabideos de Africa (sul do Saara) I. Revista Entomologia Mocambique. (1968-1969/1972) 11, 1-1088.

Forgie, S.A., Grebennikov, V.V. \& Scholtz, C.H. (2002) Revision of Sceliages Westwood, a millipede-eating genus of southern African dung beetles (Coleoptera: Scarabaeidae). Invertebrate Systematics. 16, 931-955. 
Forgie, S.A., Kryger, U., Bloomer, P. \& Scholtz, C.H. (2006) Evolutionary relationships among the Scarabaeini (Coleoptera: Scarabaeidae) based on combined molecular and morphological data. Molecular Phylogenetics and Evolution. 40, 662-678.

Forgie, S.A., Philips, T.K. \& Scholtz, C.H. (2005) Evolution of the Scarabaeini (Scarabaeidae: Scarabaeinae). Systematic Entomology. 30, 60-96.

Gillet, J.J.E. (1911) Coprophaga Africana. Descriptions d'espèces nouvelles et remarques diverses. Annales de la Société entomologique de Belgique. 55 (11), 308-312.

Griffith, E. \& Pidgeon, E. (1831) The Class Insecta arranged by the Baron Cuvier, with Supplementary Additions to each Order. Notices of New Genera and Species by G. Gray. Volume the first. In: Griffith, E. et al., The Animal Kingdom arranged in conformity with its Organisation by the Baron Cuvier, with Supplementary Additions to each Order. Volume 14 (dated 1832). Whittaker, Treacher, \& Co., London, 570 pp. 102 plates.

Harrison, J. Du G., Scholtz, C.H. \& Chown, S.L. (2003) A revision of the endemic, southwestern African dung beetle subgenus Scarabaeus (Pachysoma) Macleay, including notes on other flightless Scarabaeini (Scarabaeidae: Scarabaeinae). Journal of Natural History. 37, 305-355.

Harold, E. von (1868) Diagnosen neuer Coprophagen. Coleopterologische Hefte. 3, 80-86.

Janssens, A. (1940) Monographie des Scarabaeus et genres voisines. Mémoires du Musée royal d'Histoire naturelle de Belgique. $2^{\mathrm{e}}$ sér., 16,81 pp, 3 plates.

Johnston, H. H. (1897) British Central Africa; an attempt to give some account of a portion of the territories under British influence north of the Zambezi. Methuen \& Co, London, xix and $544 \mathrm{pp}$.

Linné, C. (1758) Systema naturae per regna tria naturae secundum classes, ordines, genera, species cum characteribus, differentiis, synonymis, locis. Salvii, Holmiae, 824 pp.

Macleay, W.S. (1821) Horae entomologicae, or essays on the annulose animals. Bagster, London, $524 \mathrm{pp}$.

Monaghan, M.T., Inward, D.J.G., Hunt, T. \& Vogler, A.P. (2007) A molecular phylogenetic analysis of the Scarabaeinae (dung beetles). Molecular Phylogenetics and Evolution. 45, 674-692.

Mostert, L.E. \& Holm, E. (1982) Notes on the flightless Scarabaeina (Coleoptera: Scarabaeidae) with a description of a new Species. Cimbebasia, 5, 273-284.

Mostert, L.E. \& Scholtz, C.H. (1986) Systematics of the subtribe Scarabaeina (Coleoptera: Scarabaeidae). RSA Department of Agriculture \& Water Supply, Entomological Memoir. 65, $1-25$. 
Olivier, A.G. (1789) Entomologie, ou histoire naturelle des insectes, avec leurs caractères génériques et spécifiques, leur description, leur synonymie, et leur figure enluminée. Coléoptères. 1, 1-190.

Péringuey, L. (1908) Descriptive catalogue of the Coleoptera of South Africa. Additions and corrections. Transactions of the South African philosophical Society. Cape Town. 13, 547752 .

Sato, H. (1998) Male Participation in Nest Building in the Dung Beetle Scarabaeus catenatus (Coleoptera: Scarabaeidae): Mating Effort Versus Paternal Effort. Journal of Insect Behaviour. 11, 833-843

Tribe, G.D. (1976) The ecology and ethology of ball-rolling dung beetles. M.Sc. thesis, University of Natal, Pietermaritzburg.

Waterhouse, C.O. (1890) New Scarabaeidae in the British Museum. The Annals and Magazine of natural History, including Zoology, Botany and Geology. 29, 365-373.

Westwood, J.O. (1837) Characters and descriptions of some new coleopterous insects belonging to the family of sacred beetles. Proceedings of the Zoological Society. 5, 12-13.

Zidek, J. \& Pokorny, S. (2004) Checklist of the genus Scarabaeus Linné. Animma.X 5, 1-30.

Zur Strassen R. (1961) Einige seltene Südafrikanische Scarabaeus arten im Museum. Frey mit einer Neu-beschreibung Entomologische Arbeiten aus dem Museum G. Frey. 12 (1), 236241

Zur Strassen R. (1963) Scarabaeus andreaei, ein neuer Pillendreher aus Mozambique. Senckenbergiana biologica. 44 (2), 107-110.

Zur Strassen, R. (1967) Arten-Übersicht der Gattung Scarabaeus Linnaeus (Scarabaeidae) mit besonderer Berücksichtigung der äthiopischen Formen. Entomologische Blätter für Biologie und Systematik der Käfer. 63 (3), 129-173. 